\title{
Müze ve Çevresel Koşulların Denetimi Açısından Denizli Atatürk ve Etnografya Müzesi ${ }^{1}$
}

\author{
Ayşegül KOYUNCU OKCA ${ }^{2}$ - Berker KALFA ${ }^{3}$
}

Başvuru Tarihi: 02.01.2020

Kabul Tarihi: 25.03 .2021

Makale Türü: Araştırma Makalesi

\section{Öz}

Kültür varlıklarını korumak ve eserleri en iyi çevre koşulları altında tutarak onları geleceğe taşımak müzelerin en temel görevini oluşturmaktadır. Gelecek nesillere iletilecek olan kültür varlıklarının çürüme, ayrılma, yıpranma ve atmosfer koşulları gibi çeşitli bozulmaları en aza indirmek ya da bozulma sürecini yavaşlatmak için gereken müdahalelerin yapılması ve tedbirlerin alınması, koruma yöntemlerinin belirlenmesi ve uygulanması çok önemlidir. Bu çalışmada Denizli Atatürk ve Etnografya Müzesi, çevresel koşulların denetimi açısından değerlendirilip, iç mekân çevre kalitesi, sergi odaları ve vitrinlerdeki ısı, ışık, nem değerleri ve dengelerinin denetim koşulları açısından uygun olup olmadı̆̆ incelenmiş ve en iyi sonuca ulaşması için çeşitli önerilerin ortaya çıkması amaçlanmıştır. Çalışmanın gerçekleşmesi için literatür taraması yapılmış, müzede görevli olan yetkili kişiler ile görüşmeler gerçekleştirilmiş, bireysel tespitler gerçekleştirilerek müze ve vitrinlerdeki çevresel koşulların denetimi gözlemlenmiştir. Ayrıca müze, teşhir odaları ve vitrinler tarafımızdan fotoğraflanarak belgelenmiştir.

Anahtar Kelimeler: Müze, Etnografya Müzesi, Çevresel Koşullar, Bozulma, Koruma

Atıf: Koyuncu Okca, A. ve Kalfa, B. (2021). Müze ve çevresel koşulların denetimi açısından Denizli Atatürk ve Etnografya Müzesi. Anadolu Üniversitesi Sosyal Bilimler Dergisi, 21(3), 683-708.

\footnotetext{
${ }^{1}$ Bu çalışma etik kurul izin belgesi gerektirmemektedir.

${ }^{2}$ Pamukkale Üniversitesi Denizli Teknik Bilimler Meslek Yüksekokulu El Sanatları Bölümü, aysegulkoyuncu@pau.edu.tr, ORCID: 0000-0003-10600280

${ }^{3}$ Pamukkale Üniversitesi Arkeoloji Enstitüsü Kültür Varlıklarını Koruma ve Onarım Anabilim Dalı Yüksek Lisans Öğrencisi, berkerkalfa@gmail.com, ORCID: 0000-0001-8428-6904
} 


\title{
Denizli Atatürk and Ethnography Museum in Terms of the Control of the Museum and Environmental Conditions
}

\author{
Ayşegül KOYUNCU OKCA ${ }^{4}$ - Berker KALFA 5
}

Submitted by: 02.01 .2020

Accepted by: 25.03.2021

Article Type: Research Article

\begin{abstract}
Preserving the cultural heritage and keeping them under the best environmental conditions and transferring them to the future is the prior task of museums. It is crucial to intervene to minimize or decelerate the deterioration process, such as corruption, deterioration, degradation and, atmospheric conditions of cultural heritages to be transmitted to future generations and to take precautions to determine and implement protection methods. In this study, the evaluation of Denizli Atatürk and Ethnography Museum in terms of the control of environmental conditions, whether the indoor environment quality, values, and balances of the temperature, light, humidity in the exhibition rooms and showcases are appropriate or not for the control conditions were investigated and various suggestions were aimed to come up with the best results. For the realization of the study, the literature was searched, interviews were conducted with the authorized personnel in the museum, and individual observations and supervision of the environmental conditions in the museum and showcases were observed. Also, exhibition rooms and showcases at the museum have been photographed and documented.
\end{abstract}

Keywords: Museum, Ethnography Museum, Environment Conditions, Deterioration, Conservation

\footnotetext{
${ }^{4}$ Pamukkale University Denizli Vocational School of Technical Sciences, Department of Handicrafts, aysegulkoyuncu@pau.edu.tr, ORCID: 00000003-1060-0280

${ }^{5}$ Pamukkale University Archeology Institute Department of Conservation and Restoration of Cultural Heritage, Postgraduate Student, berkerkalfa@gmail.com, ORCID: 0000-0001-8428-6904
} 


\section{Giriş}

Etnografya müzeleri ziyaretçilerin kendilerinin ve dünyalarının birçok yönünün farkındalığını, ilgisini ve değerlendirmesini genişleten ve değiştiren dönüştürücü bir deneyim sunan bir iletişim ortamıdır. Bu yüzden kültürel mirasa olan alakanın, etnografya müzeleri ile doğrudan ilişkisi vardır. Toplumun sosyal yaşantını yansıtan insan eli ile yapılmış etnografik eserleri içeren müzeler sadece cam vitrinlerin ardında sergilenen eserlere sahip yapıda kısıtlanmış bir kuruluş olarak düşünülmemelidir. Eserler ile ortak bir bağ kurmak, yaşanmışlıkların hissiyatını bu tür objeler üzerinden tanımlamak, ziyaretçileri eserin üretildiği dönemlere götürür ve geçmişi tanımada yardımcı olur. Günümüzde müzecilik faaliyetleri hem yöresel hem de ulusal anlamda büyük aşama kaydederek gelişme göstermiş ve ulusal birlikteliğin muhafaza edilmesi ile müzelerin çalışma alanlarını yaygınlaştırmıştır. Bu bağlamda müzeler, ulusal benliğin en temel savunucusu durumuna gelerek milli birliğin, beraberliğin ve değerlerin kuvvetlenmesine katkıda bulunmaktadır. Küçük mücevher parçalarından dev yapılara kadar her türlü eser, insanların toplumsal olarak bağlarını kuvvetlendirir. Müzeler, kendi içlerinde geçmişten günümüze birçok eseri bünyesinde barındırdıkları için insanlık tarihi, kültürel birikim, ulusal miras, deneyim ve kimliği sergilemek açısından önemli bir yere sahiptir.

Müzelerde bulunan koleksiyonlar, milletlerin geçmiş kültürel zenginliğine göre çeşitlilik gösterir. Etnografya müzelerinde somut ve somut olmayan kültürel mirasa ait eserlerin gösterimi o yöredeki yaşanmışlıkları belgeler ile aktarmaktadır. Bu belgelerin en iyi şekilde korunarak etki altında kaldıkları tehditlerin engellenmesi, saklama, sergileme koşulları ve eserlerin uygun bir şekilde teşhir edilmesi müzelerin esas görevleri arasındadır.

Bu çalışmada Denizli Atatürk ve Etnografya Müzesi, çevresel koşulların denetimi açısından değerlendirilip, iç mekân çevre kalitesi, sergi odaları ve vitrinlerdeki 1sı, 1şık, nem değerleri ve dengelerinin denetim koşulları açısından uygun olup olmadığı incelenmiş ve çeşitli önerilerin ortaya çıkması amaçlanmıştır. Çalışmanın gerçekleşmesi için literatür taraması yapılmış, müzede görevli olan yetkili kişilerle görüşmeler gerçekleştirilmiş, bireysel tespitler ile müze ve vitrinlerdeki çevresel koşulların denetimi gözlemlenmiştir.

\section{Müze Kavramı ve Etnografya Müzeleri}

Müze kavramı; Uluslararası Müzeler Komitesi (ICOM) tarafından "Toplumun ve gelişiminin hizmetinde olan halka açık insana ve yaşadiğı çevreye tanıklık eden malzemelerin üzerinde araştırma yapan, bu malzemeleri toplayan koruyan, bilgiyi paylaşan ve sonunda inceleme eğitim ve zevk alma doğrultusunda sergileyen, kar düşüncesinden bağımsız bir kurum" olarak ifade edilmiştir (ICOM, 2017, art. 3). Toplamak ve biriktirmek müze kavramının temelini oluşturmuştur (Altınsapan ve Küçükhasköylü, 2013, s. 3). Müzeler; toplumların ve insanlık tarihinin somut olan bir belgesi, kültür ve medeniyetin en kuvvetli aktarımı olan farklı eserlerin korunup sergilendiği ve yorumlandığı yerlerdir (Lewis, 2004, s. 1). Müzeler kişileri yönlendirerek ve zaman, mekân anlayışının giderek gereksiz hale geldiği günümüz dünyasında keşifler yapmaya yardımcı olmaktadır (Lumly, 1988, s. 18). Bir kurum olarak hem kozmopolit hem de evrensel versiyonunun dünya çapında genişlemesini yaşayarak belirli kültürel kimliklerin tanıtımını yapmakta ve disiplin tarihi gelişimi için odak noktası sağlamaktadır (Poulaot, 2013, s. 29).

Sergilemeye sahip kültürel kurum olarak müzeler, objeleri, eserleri ya da örnekleri toplayan, belgeleyen ve koruyan, araştırma ve etkinlikleri gerçekleştiren, öğrenme amacı ile sergileme ve yorumlama işlevlerini yerine getiren kurumlardır (Fromm, 2016, s. 89; Doğruer, 2019, s. 124). Akademik alanda tartışmalar yaratma ya da uygulama alanındaki yakınsama odaklarından bağımsız olarak müze, araştırmacılar tarafından, insanlık tarihinin, kültür ve medeniyetinin içerdiği anlamları aktararak yorumlama ve aracılık etmedeki sosyal önemi nedeni ile farklılıklar göstermektedir ( $\mathrm{Lu}, 2017$, s. 443). James Sheehan müzeler için, kendi tarihlerinin entelektüel, kurumsal ve mimari izleri, kendi geçmişlerinin kalıntılarıdır diyerek (Sheehan, 2000, s. 189) politik 
ve sosyal hedeflere ulaşmada vatandaşın ahlaki ve entelektüel davranışını etkilemek ve belirli tarih ya da kültür görüşlerinin bir kanıtı olarak ulusal kimliğin beyanlarını sağlamak için kurulduğunu belirtmiştir. Müzeler bir toplumun hem kendi geçmişine hem de yaşadığı çevredeki geçmiş uygarlıklara ait eserler sunarlar. Bu durum müzelerde merak eden, çalışmak isteyen, araştırma yapan, görmek isteyen pek çok yerli ve yabancı insanı buluşturur (Buyurgan ve Mercin, 2010, s. 20). Çağdaş müzecilik anlayışı çerçevesinde çalışmalarını ve araştırmalarını yürütecek insanlar için hem arkeoloji müzeleri hem de etnografya müzeleri birer eğitim kurumu haline dönüşmüştür (Atasoy, 1994, s. 38).

Etnografya, toplumların kültür unsurlarını bütünü ile inceleyen gelişim ve ilerlemelerini anlatan, yaşam şekillerini ve düşünce yapılarını ifade eden bir kültür bilimidir (Bülbül 2016, s. 217). Bu toplumların kültür yansımalarını nesneler ile aktaran mekanlar ise etnografya müzeleridir. Bu müzeler genel anlamda toplumların unutulan ya da yaşamakta olan etnografik kültürlerine ait eserleri toplayan ve bunları sergileyen yapılar olarak karşımıza çıkmaktadır. Kültürel değerlerin, birikimlerin, sanatsal değerlerin ifade edildiği, insan deneyiminin ilişkilendirildiği (Steen, 2004, s. 183) ve ulusal belleğin şekillendiği kurumlar olan etnografya müzeleri bu yönleri ile ülke kültürünün kimliğini meydana getirirler. Yaygın olarak Avrupa'da bulunan etnografya müzeleri Amerika, Asya ve Afrika'da da yer almaktadır. Türkiye'de etnografya müzelerinin kurulması 1924 yılına tarihlendirilmektedir (Öztürk 2003, s. 65). Folklor, halk sanatı ve gelenekleri ile ilgili olan etnografya müzeleri Selçuklu, Osmanlı ve Erken Cumhuriyet Dönemini kapsamaktadır (Buyurgan ve Mercin, 2010, s. 20).

\section{Denizli Atatürk ve Etnografya Müzesi}

Yapıların toplumları etkilemesi ve eğitmesi için yüceltici bir anlam kazanması gerekmektedir. Bunu yapmanın en iyi yolu ise onları yaşayan birer varlık durumuna getirmektir (Altınoluk, 1988, s. 14). Eski yapıların çağdaş kullanım amacı ile değerlendirilmesi ve teknolojinin tüm olanaklarından faydalanılarak sürekliliğin sağlanması hem sanat hem de tarihe saygı açısından önemlidir. Yeni fonksiyonlar kazandırırken eski yapıların mevcut durumlarına olabildiğince sağdık kalınması ve yapıdaki zaman katmanlarının korunması onu bir dönemin izlerini yok etmekten kurtararak gelecek nesiller için farklı yorumlanmasını engeller. Venedik Tüzüğü’nün 5. maddesine göre, Anıtların korunması onları sosyal olarak faydalı bir amaç için kullanmak ile kolaylaştırılabilir. Bunun için bu tür bir kullanım istenmektedir ancak yapının planı veya süslemeleri değiştirilmemelidir. Bu çizgiler dâhilinde işlev değiş̧ikliği öngörülebilir ve buna izin verilebilir (ICOMOS, 1964, art. 5). Bu madde ile yeniden kullanım konusu belirlenmiştir. Yaşayan varlık durumuna gelen, onu topluma yararlı kılan, toplumun ve çevresinin yapı ile bütünleşmesini sağlayan ve yaşamımızın bir parçası haline gelen Denizli Atatürk ve Etnografya Müzesi, yeniden fonksiyon kazandırılan yapılara güzel bir örnek teşkil etmektedir (Bkz. Şekil. 1-2).
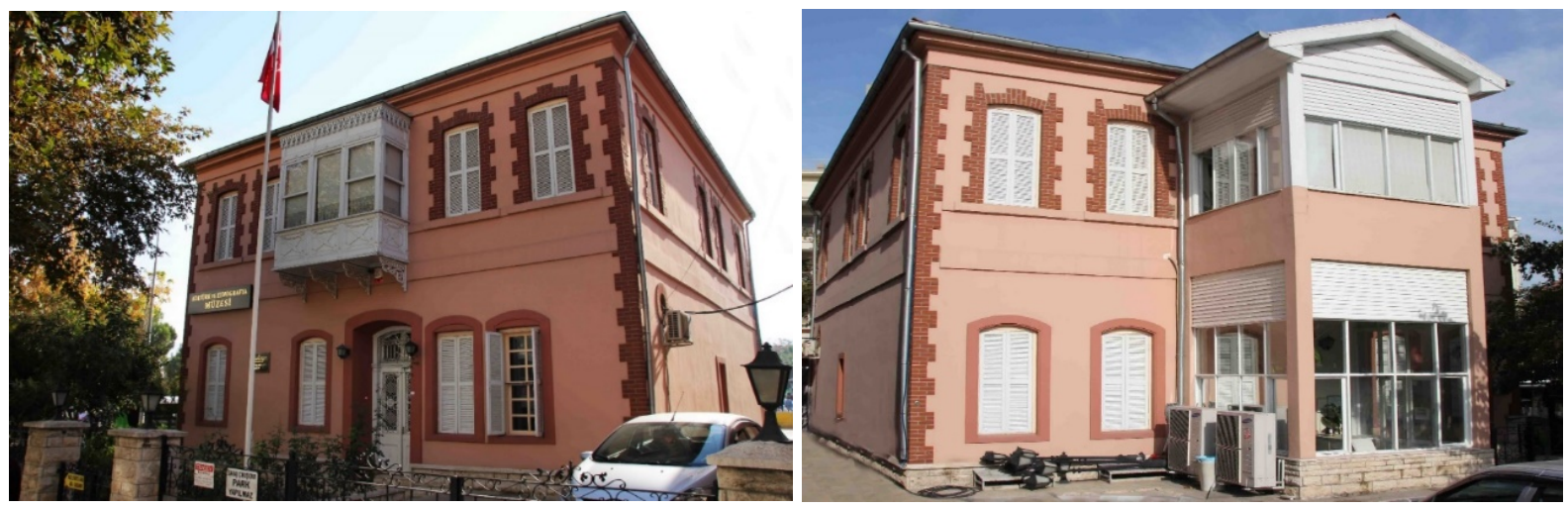

Şekil 1-2. Denizli Atatürk ve Etnografya Müzesi 
Denizli İli, Merkezefendi İlçesi, Saraylar Mahallesi 459 nolu sokakta yer alan ve bugün müze olarak kullanılan yapının Kimon Vandazoflus tarafından yaptırıldığı fakat yapım tarihi ile ilgili kesin bir bilgi olmaması ile birlikte 19. yüzyılın sonlarında inşa edildiği düşünülmektedir (Koyuncu Okca ve Özar, 2015, s. 198). Yapının cephesi sade görünmek ile beraber özellikleri, pencere formu, süsleme detayları sakız mimarisi ile örtüşmektedir.

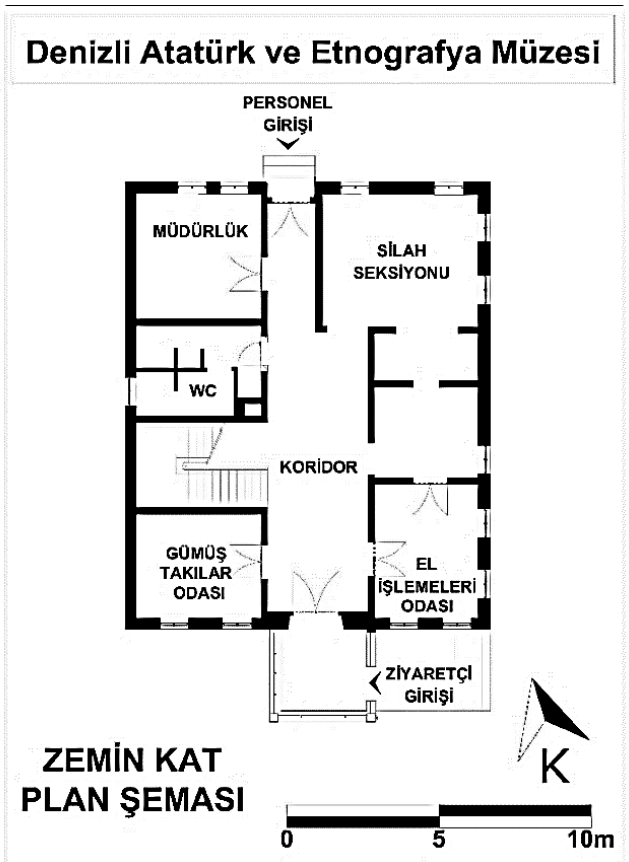

Plan 1. Denizli Atatürk ve Etnografya Müzesi, Zemin Kat Plan Şeması

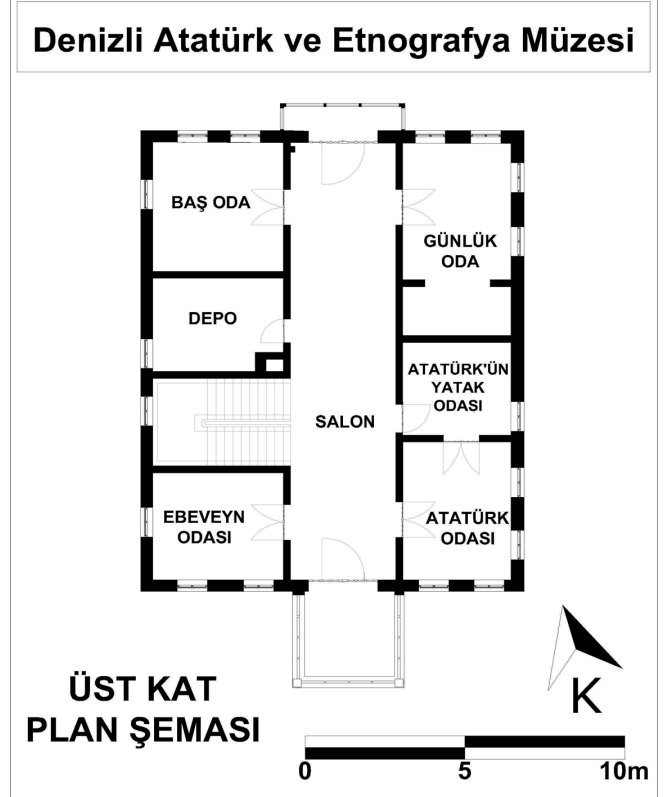

Plan 2. Denizli Atatürk ve Etnografya Müzesi, Üst Kat Plan Şeması 
Sakız mimarisi, 19. yüzyılın ilk çeyreğinde Sakız Adası'ndan gelen usta ve zanaatkârların geleneksel mimarimize katmış olduğu aynı zamanda zenginleştirdiği farklı üslup ve tekniklerdir. Bu ustaların İzmir ve çevresi ile İstanbul gibi kentlerde yapmış olduğu evleri yöre halkı "sakız tipi ev” olarak adlandırmıştır (Çıkış, 2009, s. 220 - 221). İki katlı olarak inşa edilen yapı, plan itibari ile zemin katta bir salon ve kapıları bu salona açılan odalar (Bkz. Şekil. 3-4) ile üst katta ise geleneksel mimaride evin en etkileyici bölümü olan sofa ve bu sofaya açllan odalardan oluşmaktadır (Baysal ve Kayhan, 2016, s. 14).

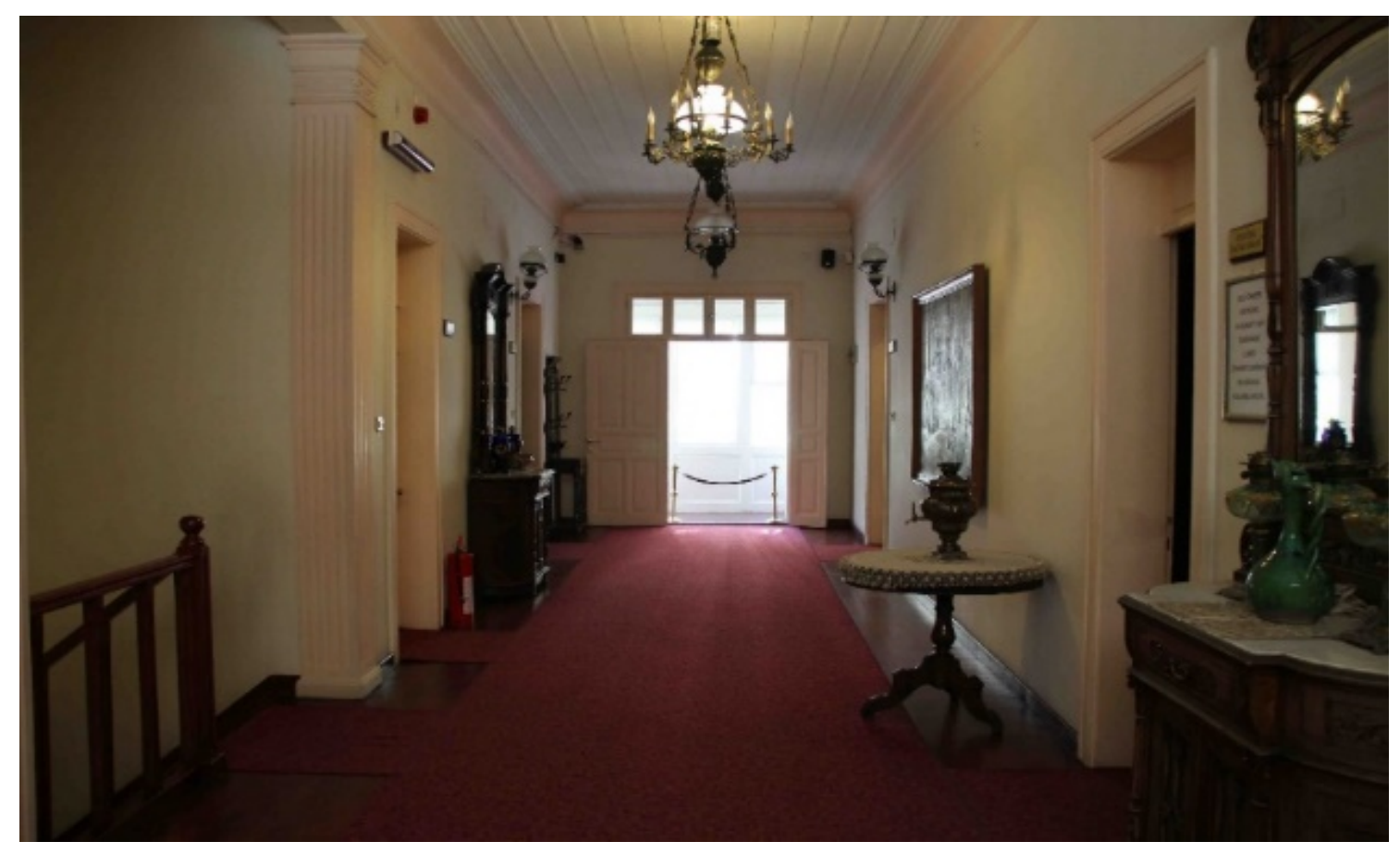

Şekil 3. Zemin Katta Bulunan Salon ve Üst Katta Bulunan Sofa

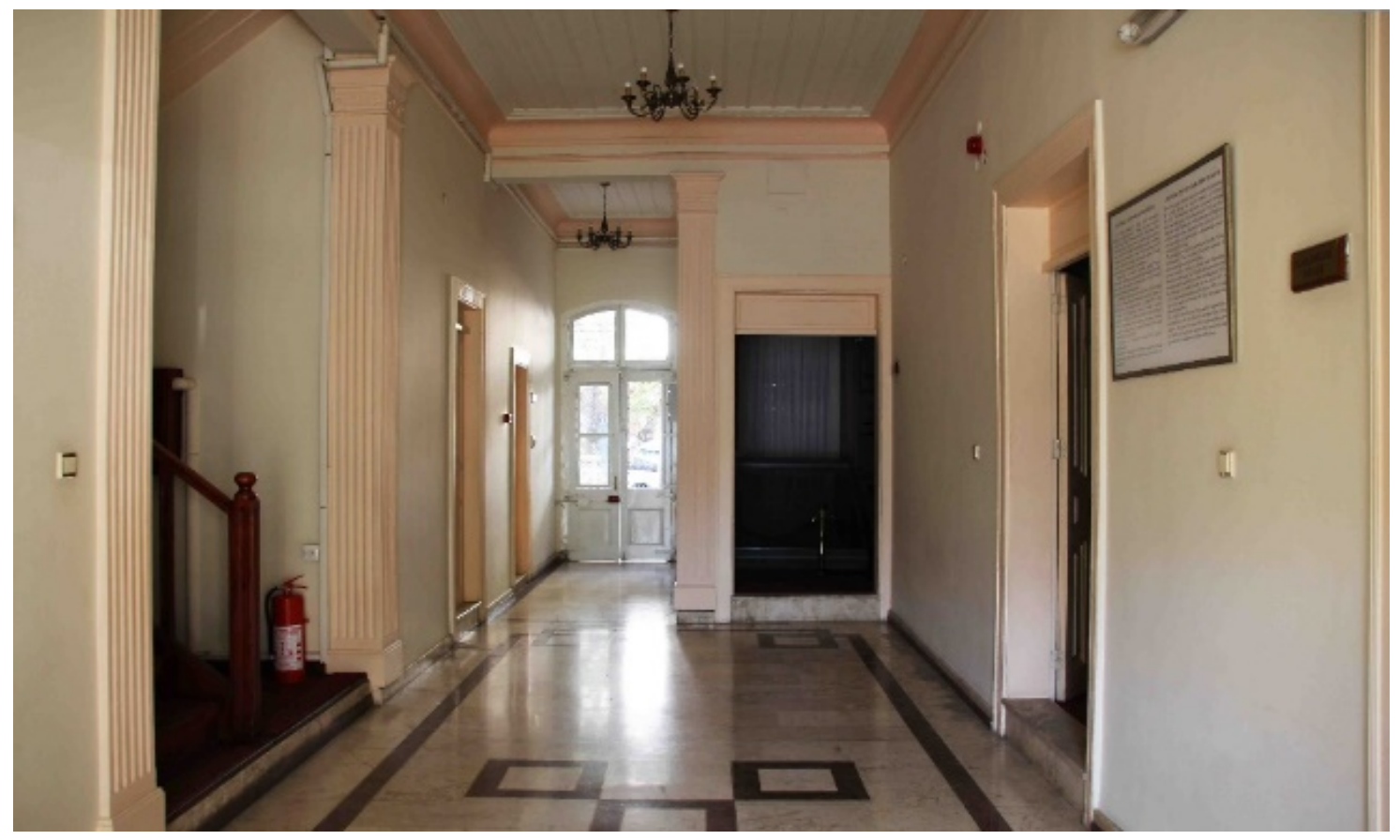

Şekil 4. Zemin Katta Bulunan Salon ve Üst Katta Bulunan Sofa 
Giriş kapısının üstünde cepheyi hareketlendiren, odayı büyüten, girişi yağmur ve kardan korumak için yapılmış çıkma yer almaktadır. Yapının tüm cephelerinde bulunan pencereler basık kemerli dikdörtgen şeklindedir (Ötgün, 2007, s. 78). Beden duvarları kargir, ara duvarlar ise ahşap karkas şeklinde inşa edilmiştir. Yapı beşik çatılı olup, Marsilya tipi kiremit ile örtülüdür (Baysal ve Kayhan, 2016, s. 14). Yapı, Cumhuriyetin erken döneminde Cumhuriyet Halk Partisi (Fırka) binası olarak kullanılmış ve Ulu Önder Atatürk, 4 Şubat 1931 tarihinde Denizli'ye gelişinde bu binada bir akşam misafir edilmiştir. 1950 yılından itibaren Sağlık Bakanlığı'na ayrılan bina Verem Savaş Dispanseri olarak hizmet vermiştir. Bu süreçte zamana karşı yorgun düşen yapı terk edilmiştir (Oran, 1974, s. 46). Bina, 1977'de anıt eser olarak tescil edilmiş 1980-1983 yılları arası bakımı ve düzenlemesi yapılmış, 1 Şubat 1984 tarihinde teşhir tanzim çalışmaları bitirilmiş ve müze olarak hizmete açılmıştır (Baysal ve Kayhan, 2016, s. 14). Zaman içinde atmosfer koşullarından olumsuz etkilenen yapı yıpranmış ve yeniden bakıma ihtiyaç duymuştur. 1997 yllı sonunda tekrar restorasyon çalışmaları başlamıştır (Karabay, 2007, s. 4). Restorasyon ve yeniden yapılan teşhir tanzimi ile Atatürk'ün Denizli'yi ziyaret edişinin 68. yılı olan 4 Şubat 1999 tarihinde yeniden açılmıştır (Ötgün, 2007, s. 78). Tarihi yapıların sürekli bakıma ihtiyacı vardır bu yüzden periyodik olarak onarım ve bakımlarının yapılması gerekir. Son olarak Aralık 2006'da restorasyonu yapılarak, 4 Şubat 2007 tarihinde ziyarete tekrar açılmıştır (Baysal ve Kayhan, 2016, s. $14)$.

Müzenin giriş katında etnografik eserler, el işlemeleri odası, silah seksiyonu ve gümüş takılar odası yer almaktadır. Üst katında ise Atatürk'ün çalışma ve yatak odası ile tarihi Denizli evini temsil eden odalar bulunmaktadır. Ziyaretçiler müzeye girdiklerinde sol ve sağ tarafta bulunan iki oda göreceklerdir. Sağ tarafta bulunan el işlemeleri odasında ocak örtüsü, Kuran-1 Kerim kabı, gaz lamba haznesi, para kesesi, fincanlar, gümüş takılar, fincan zarfları, limon çatalı, çay kaşıkları, kesme şeker maşası, süslemeli şekerlik kapağı, hamam takımı, gümüş kemer ve tokaları, geleneksel kadın giysileri, para-mühür-saat keseleri, köstekli saatler cam kapaklı yer vitrininde ve duvar vitrinlerinde teşhir edilmektedir. Ayrıca kilim ve telgraflar bulunmaktadır (Bkz. Şekil. 5).

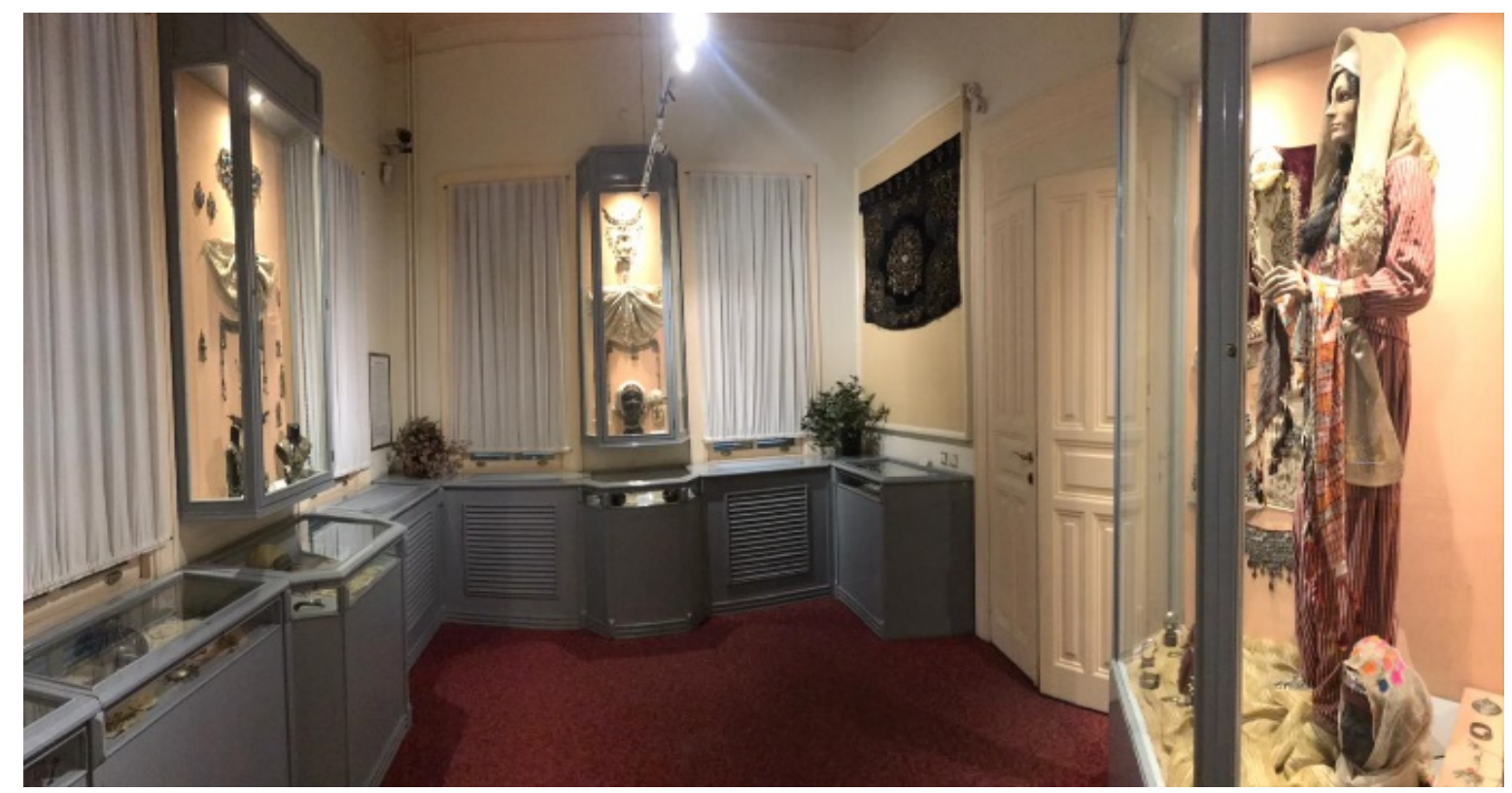

Şekil 5. El İşlemeleri Odasından Genel Bir Görünüm 
Girişte sol tarafta gümüş takıların yer aldığı bir oda bulunmaktadır. Bu odada gümüş ziynet eşyaları, peşkirler, başörtüsü, hamam takımları, bafon (gümüş görünümlü) takılar, bezenmiş dokuma örnekleri, cepkenler, gümüş bilezikler, kolyeler, kemerler, para-mühür ve saat keseleri, muskalıklar ve kahve takımları cam kapaklı yer vitrininde ve duvar vitrinlerinde teşhir edilmektedir (Bkz. Şekil. 6).

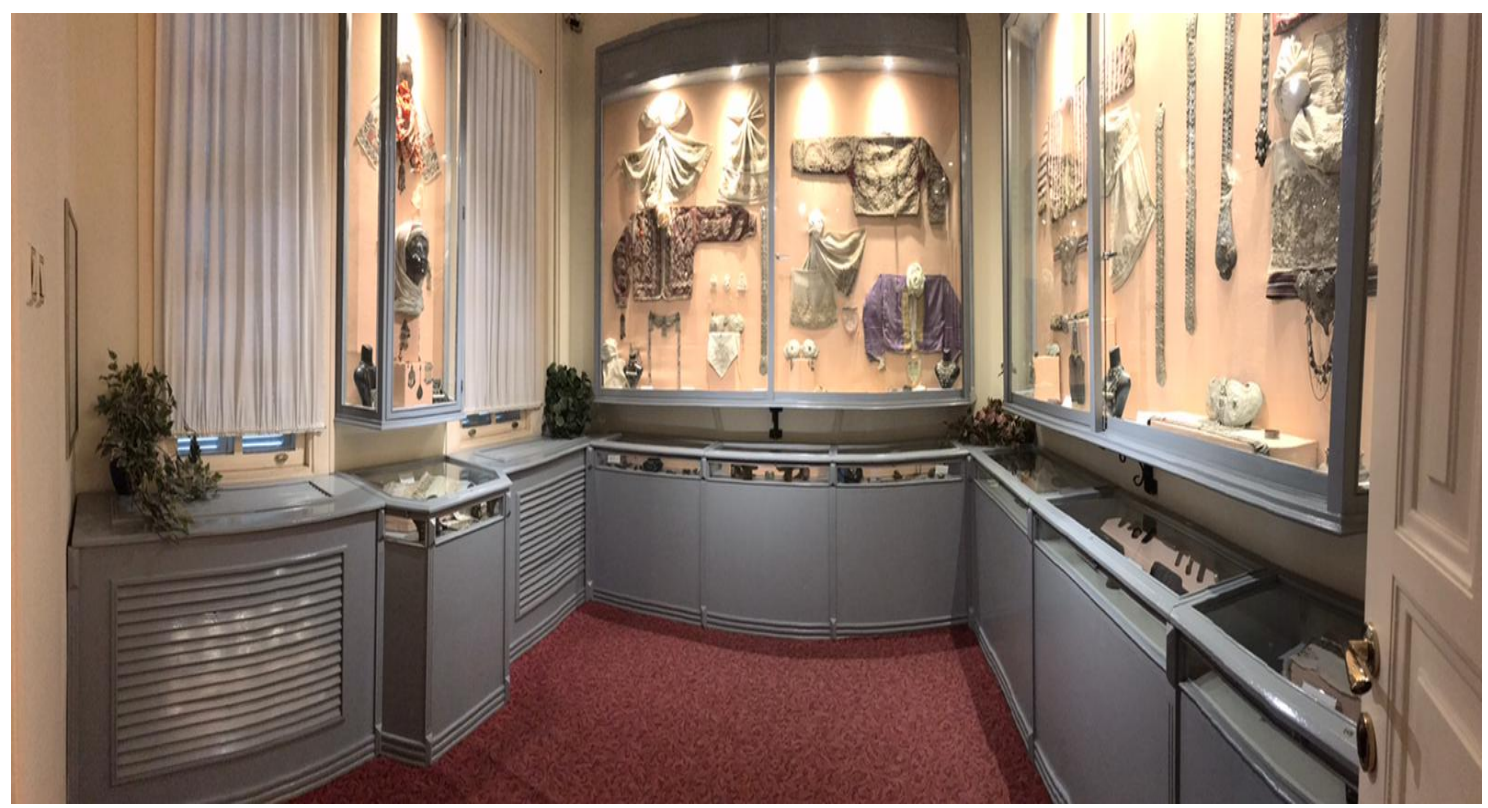

Şekil 6. Gümüş Takıların Yer Aldığı Odadan Genel Bir Görünüm

Alt katta en geniş üçüncü odada tüfek, pala, kılıç, tabanca, Denizli Sancağı, uçkurlar, peşkirler ve Selcenli Hüseyin Efe'ye ait giysiler sergilenmektedir (Bkz. Şekil. 7).

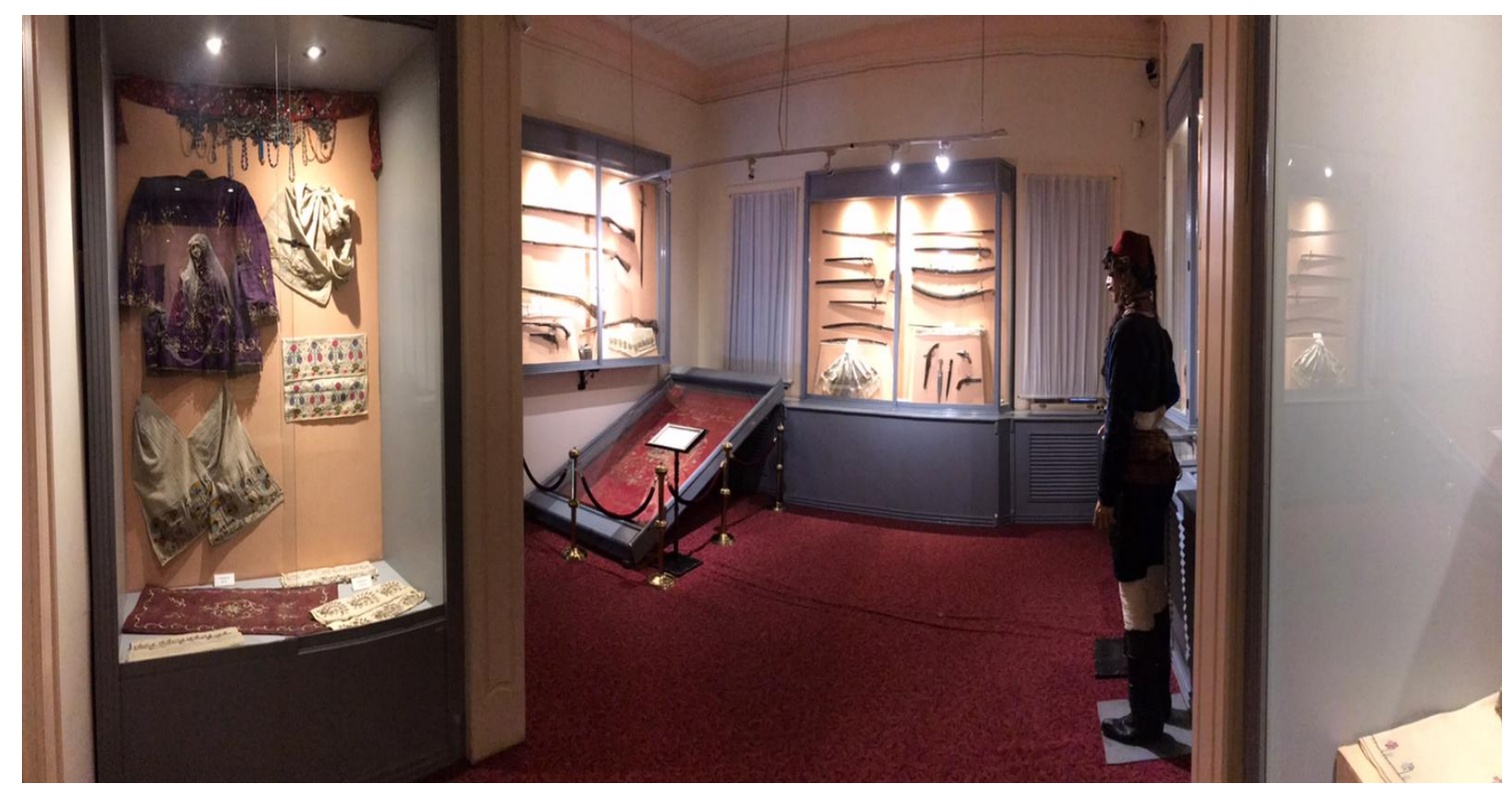

Şekil 7. Silah Seksiyonu, Denizli Sancağı ve Selcenli Hüseyin Efe’ye Ait Giysinin Sergilendiği Odadan Genel Bir Görünüm 
Üst katta Atatürk'ün yatak odası, Atatürk'ün çalışma odası, günlük oda, başoda ve ebeveyn odası bulunmaktadır. Atatürk odasında Denizli’ye geldiği zaman kullanmış olduğu eşyalar bulunmaktadır. Bu odada istirahat etmesi için bir divan, çalışma masası, pikap, içerisinde cam bardakların bulunduğu bir adet büfe, fincanların bulunduğu ayrı bir büfe, radyo, aynalı iki kapaklı gardırop ve Atatürk'ün Denizli' de çekilmiş olduğu fotoğrafları sergilenmektedir (Bkz. Şekil. 8). Atatürk'ün 4 Şubat 1931 tarihinde bir gece konakladığı odada ise pirinç başlıklı bir karyola, yatak, ahşaptan tek kapaklı aynalı bir adet gardırop, telefon ve bir adet ahşap sandık sergilenmektedir (Bkz. Şekil. 9).

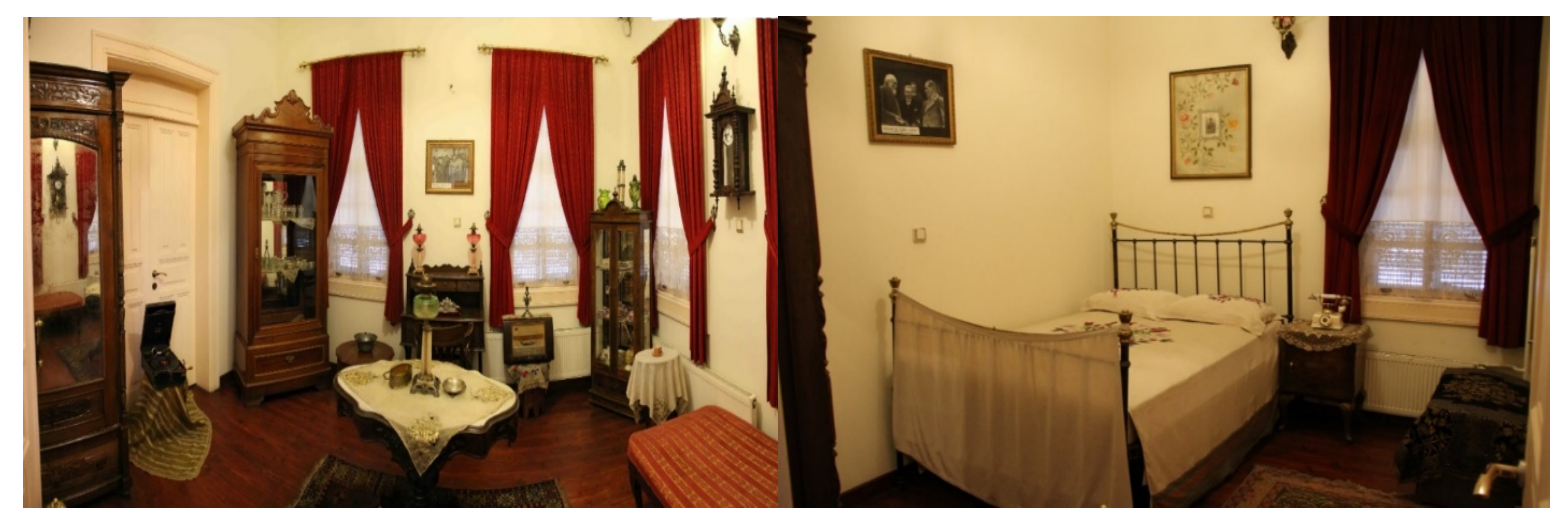

Şekil 8-9. Atatürk'ün Çalışma ve Yatak Odasından Genel Görünüm

Günlük odada ise, geleneksel Denizli ailesinin günlük yaşamından bir kesit sunulmuş, sedir üzerinde oturan bir kadın, beşikteki bebeği ile ilgilenen bir anne, ocakta kahve pişiren bir başka kadın, tam merkezde sini ve yemek yiyen bir çocuk sergilenmektedir (Bkz. Şekil. 10). Başodada sedirler üzerinde el işlemeleri ile ilgilenen kadınlar, ortada kurulmuş sinili yemek sofrası, bakır yemek kapları, boy aynası, ütü, bakır mangal ve döküm soba sergilenmektedir (Bkz. Şekil. 11). Ebeveyn odasında sedirler üzerine oturan iki kadın bir yaşlı adam ve ayakta duran bir kadın tasvir edilmiştir. Geleneksel Türk ailesinin temsil edildiği bu odada evin reisi, nine ve diğer aile bireyleri sergilenmektedir (Bkz. Şekil. 12).

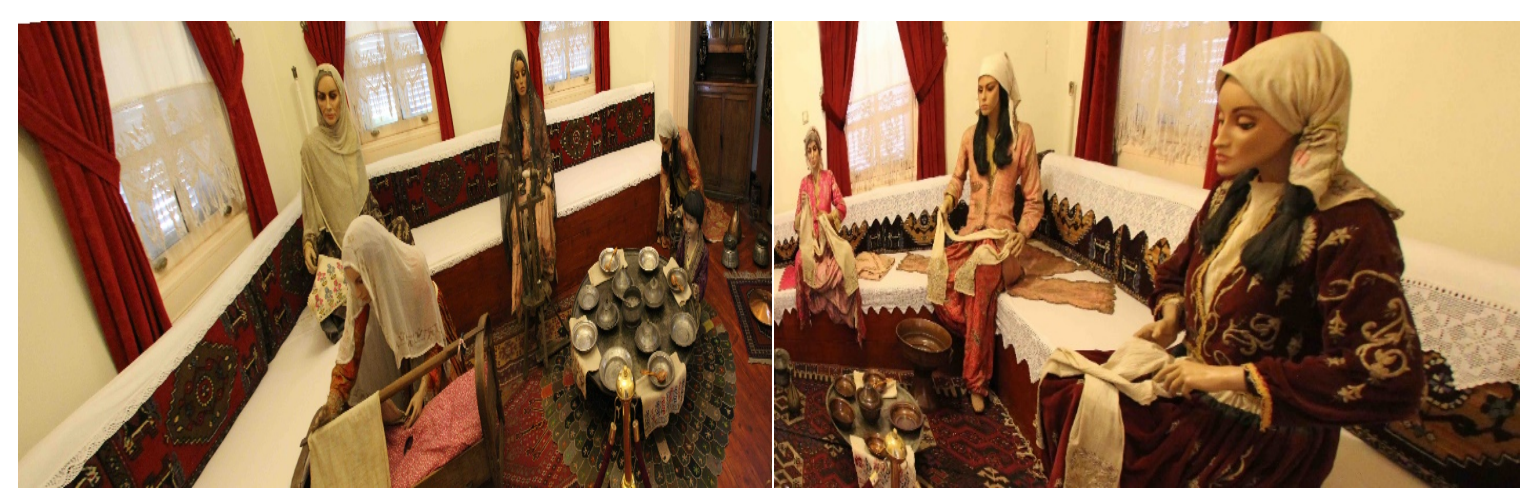

Şekil 10-11. Günlük ve Başodadan Genel Bir Görünüm 


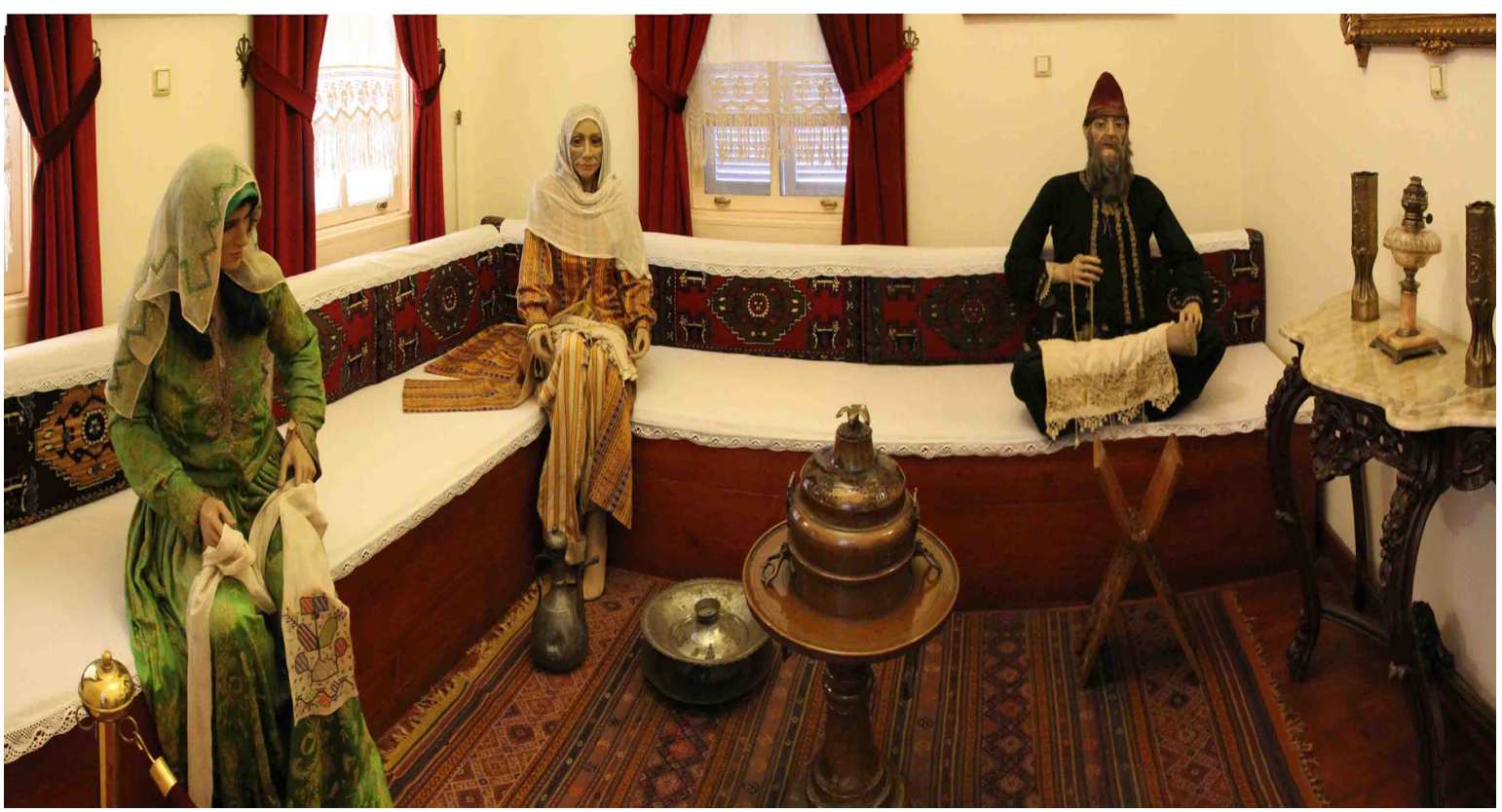

Şekil 12. Ebeveyn Odasından Genel Bir Görünüm

\section{Etnografik Eserlerin Müzelerde Bozulma Durumları ve Çevresel Faktörler}

Geçmişten gelen, tarihi, kültürel değer taşıyan eserleri korumak ve onlara en iyi çevre koşullarını sağlamak müzelerin en temel ve birincil sorumluluğudur (Kocaeli ve Eskici, 2017, s. 52). Geleceğe iletilmesi gereken bu kültür varlıklarının sergilendiği, depolandığı ortamlarda ve müzelerde, çürüme, yıpranma, atmosfer koşulları gibi her türlü bozulmanın önüne geçecek önlemlerin alınması, koruma yöntemlerinin belirlenerek planlanması, ideal bakımı sağlayacak koşulların oluşturulması önem arz etmektedir (Ayaokur, 2014, s. 21). Eserlerin uygun bir şekilde depolanması, önleyici bakımın kritik bir yönüdür. Eserler, uygun kontroller ile hırsızlık, yangın ve fiziksel güçlerden korunabilir; zararlı kimyasal reaksiyonlar dikkatli malzeme seçimi ve ortamların kontrolü ile hafifletilebilir; politikaların, prosedürlerin ve eğitim programlarının uygulanması malzeme kaybını ve hasarını azaltabilir (Rose vd., 2019, s. 46). Ülkemizde kültür varlıklarının korunması, restorasyon ve konservasyonları, depolama ve sergileme ortamlarının araştırılması, bozulmalarının tespiti, analizlerinin yapılması amacı ile İstanbul merkez kabul edilerek Ankara, Antalya, Bursa, Diyarbakır, Erzurum, Gaziantep, İzmir, Nevşehir ve Trabzon illerinde restorasyon ve konservasyon bölge laboratuvar müdürlükleri kurulmuştur. Ayrıca Kültür ve Turizm Bakanlığı son yıllarda muhtelif müzelere uzman restoratör/konservatör atayarak bu alandaki eksikliklerin giderilmesi için çalışmalar yapmaktadır. Ancak halen daha birçok müzede uzman restoratör/konservatör kişilerin olmaması maalesef bakıma muhtaç, yorgun, yıpranmış ve yok olmaya yüz tutmuş eserler açısından üzücü bir tablo sergilemektedir.

Müzeye yeni gelen eserlerin iyi bir şekilde belgelenmesi (Stiff, 2007, s. 4), yetkin restoratör/konservatör tarafindan durumunun incelenmesi varsa bozulma durumunun tespit edilip pasif ve aktif koruma çalışmalarının yapılması, depolama ve sergileme için uygun çevre koşullarının sağlanması gerekmektedir (Boersma, 2016, s. 5). İnorganik ve organik kültür varlıklarının bozulmaları üç şekilde gerçekleşir.

- Kimyasal Bozulma: Hava kirliliğine bağlı asidik etki ve oksidasyon sonucu yapısal bozulmalar görülür. Özellikle formaldehit ve uçucu organik asitler, müze ortamındaki eserlerin bazı hasarlarından sorumlu kirleticiler olarak kabul edilmiştir. Müze yapılarının inşasında ve taban döşemelerinde dikkat edilmeden seçilen ve kullanılan malzemeler de bu tip kirleticilere ortam hazırlamaktadır (Stulik vd., 1991, s. 364). Sanat eserleri, mikro klima etkilerine, iç mekanlarda bulunan gaz kirleticilerin doğrudan etkisine ve dışarıdaki gazların müze içine sızmasına karşı korunmalıdır (Uring vd., 2020, s. 42850). 
- Fiziksel Bozulma: Isı ve nem oranlarının ani değişimleri, gece ve gündüz arasındaki sıcaklık farkları kültür varlıklarındaki bozulmaları da beraberinde getirir. Yapısal bozulma sonucu oluşan çatlamalar, kırılmalar, parçalanmalar ve şekil değişiklikleri bu bozulma türüne örnektir.

- Biyolojik Bozulma: Fareler, böcekler, kuşlar ile algler, yosunlar, likenler, bakteriler, mantarlar gibi mikroorganizmaların neden olduğu bozulmalardır (Erdal, 1989, s. 323). Bu tür canlılar kültür varlıklarında ve özellikle organik eserlerde büyük tahribata neden olabilirler (Koçak ve Eskici, 2019, s. 244). Nemli ortam, sıcaklık ve havalandırma eksikliği gibi çevresel etkenler de biyolojik bozulmaların oluşmasına yol açabilirler (Beşkonakl1, 2010, s. 116).

Algler, dünyanın oksijen rezervinin büyük bir bölümünü karşılar, tek hücreli canlılardır, koloniler şeklinde oluşurlar, değişik renklerde olabilirler, binlerce türleri vardır, ışık ve suya ihtiyaçları vardır bunlardan birini kesildiğinde ölebilirler. Neme ihtiyaç duydukları için yapının nem oranını arttırırlar. Algler üzerlerinde başka biyolojik canlıların yetişmesi için ortam sağlamış olurlar bu bakımdan tehlikelidirler.

Likenler, çevre koşulları uygun olmadığı zaman inaktif durumdadırlar, çevre koşulları uygun hale gelince aktif hale geçerler. Değişik renklerde değişik desenlerde olabilirler. Sarı, siyah, kahverengi gibi renkleri vardır. Herhangi bir toprak desteğine ihtiyaçları yoktur yapıştı̆̆ yüzeyde kendisi toprak oluşturduğu için başka biyolojik canlılara zemin hazırlarlar bu bakımdan tehlikelidirler (Caneva vd., 1991, s. 96).

Bakteriler dünya üzerinde en fazla popülasyona sahip türlerdir. Hayatlarını sürdürebilmek için organik asitler salgılarlar (sülfürik asit ve nitrik asit) ve bu asitler mermer, kireç taşı gibi taşlara zarar vererek bozulmasına neden olurlar (Dolar ve Yılmaz, 2014, s. 3). Mantarlar da tıpkı bakteriler gibi sülfürik ve nitrik asit üreterek eserlere zarar vermektedir. Kağıt, ahşap, tekstil, parşömen gibi organik materyaller, onları bir besin kaynağı olarak kullanan bakteri ve mantar mikroflorasının saldırısına maruz kalır (Caneva vd., 2003, s. 5). Organik yapıya sahip bu materyaller nemli ve havalandırma eksikliği olan ortamlarda küf ve bakterilerin saldırısına maruz kalarak çürümeye mahkum olmaktadırlar (Plenderleith, 1957, s. 95).

Tablo 1.

Biyolojik Oluşumların Farklı Malzemelerdeki Yoğunluğu (De Nuntiis vd., 2012, s. 23).

\begin{tabular}{|c|c|c|c|c|c|c|}
\hline$\underline{\text { Mikroorganizma }}$ & $\begin{array}{l}\text { Ototrof } \\
\text { Bakteri }\end{array}$ & $\begin{array}{c}\text { Heterotrof } \\
\text { Bakteri }\end{array}$ & Mantar & Alg & Liken & Yosun \\
\hline \multicolumn{7}{|l|}{$\underline{\text { Organik Malzeme }}$} \\
\hline Ahşap & - & +++ & ++++ & + & + & - \\
\hline Kâğğt & - & +++ & ++++ & - & - & - \\
\hline Tekstil & - & ++ & +++ & - & - & - \\
\hline \multicolumn{7}{|l|}{ İnorganik Malzeme } \\
\hline Taş & +++ & ++ & ++ & ++++ & ++++ & ++++ \\
\hline Cam & ++ & - & - & ++ & ++ & - \\
\hline Metal & ++ & - & - & ++ & + & - \\
\hline \multicolumn{7}{|c|}{ Lejant: (-) yok } \\
\hline
\end{tabular}


$\mathrm{Bu}$ bozulma türlerine galvanik bozulma da eklenebilir. İki ayrı metalin birlikte olması durumunda elektrokimyasal reaksiyon sonucu hangi metalin yapısı daha zayıf ise o metalde bozulmalar görülecektir. Bu durum diğer metali de etkileyerek bozulmasına neden olacaktır. Dolayısı ile müze depolarında iki farklı eser birlikte tutulmamalı veya paketlenmemelidir bu yüzden ayrı raflarda depolanmalıdır. Bu bozulmalara sebep olan etmenler ortadan kaldırıldıktan sonra amaç onları uygun ortam koşullarında sergilenmek, depolamaktır. Eser veya eserler daha sonra seksiyon sorumlusu ve uzman konservatörler tarafından sergilenmeye uygun olup olmadığı belirlenerek teşhir edilebilir.

Etnografik eserlerin sergileme amacı ile yerleştirildiği ortam ve yerleştirilme şekline özen gösterilmelidir. Kültür varlıklarının açı alanda sergilenmesi, organik eserlerin iğneler ya da demir çiviler ile duvara tutturulması, uzun süre askıda kalan organik eserlerde esneme ve kopmaların görülmesi beraberinde is, kir, solma gibi problemler ile karşılaşılması, eserin bir başka eser ile temas etmesi gibi yanlış uygulamalardan kaçınılmalıdır. Geleneksel hayatı yansıtan sergileme alanları oluşturulurken bazı objeler etnografik eserler özellikle dokumalar- ile doğrudan temas etmekte ve bu durum eserlere zarar vermektedir. Etnografik eserlerde bu tarz bir sergileme alanı oluşturulacak ise mümkün olduğunca iki nesne arasına mukavva, karton ya da asitsiz kâğıdın yerleştirilmesi gerekmektedir (Ünaldı, 2019, s. 81).

Müzelerdeki kültür varlıklarının bozulma sürecine etki eden önemli faktörlerden biri; eserleri oluşturan özgün materyal ve yapı sistemindeki materyalin fiziksel ve kimyasal uyumları olmakla birlikte, kullanım biçimleri ve yer aldıkları ortamdaki çevre koşullarından etkilenmesidir. Müzelerdeki konfor koşullarını meydana getiren parametrelerde oluşacak riskler (1şık, 1sı, bağıl nem ve dalgalanmaları, biyolojik faktörler, atmosferik faktörler vb.) eser sağlığını tehdit etmektedir (Kuzucuoğlu, 2011, s. 68; Putt ve Slade, 2004, s. 5).

\section{Isı ve Nem}

Nem, 1sı, ışık ve havanın kalitesi gibi ortam koşullarının uygun olması eserin stabil durumu için çok önemlidir. Isı sabit olarak normal oda sıcaklığı koşullarında $18-21^{\circ} \mathrm{C}$ arasında tutulmalı (Al-Saad, 2013, s. 36), bazı yerlerde kaloriferlerin gündüz açlıp, gece ise kapatıldığı bilinmektedir. Fakat 1sıtma sistemleri gece ya hiç söndürülmemeli ya da hiç yakılmamalıdır. Bu tip ısı değişimleri bozulma süreçlerini hızlandırır. Sıcaklığın eserlerde bozulma durumuna doğrudan değil dolaylı olarak etkisi vardır bu da bağıl nem düzeyini etkilemesidir (National Park Service, 2016, s. 4:9). Bağıl nem, kapalı bir mekânda havadaki su buharı yüzdesi ile havanın taşıyabileceği maksimum su buharı arasındaki orana denilmektedir (Schultz, 1992, s. 23). Bağıl nemin yükselmesinde kalabalık ziyaretçi grubunun nefesi ve terlemesi gibi etkenler rol oynamaktadır (Kökten 2007, s. 101). Sıcaklık yükseldikçe bağıl nem düşer, sıcaklık düştükçe bağıl nem yükselir ve eserler de bu duruma ayak uydurmaya çalışır yani bağıl nem yüksek ise nem alırlar, düşük ise nem verirler. Bu olayın sürekli tekrarlanması sonucu özellikle neme duyarlı organik eserlerde kırılma, ufalanma hatta kaybedilmesi gibi bozulmalar görülür. Sıcaklığın sabit tutulması bu yüzden önemlidir. 


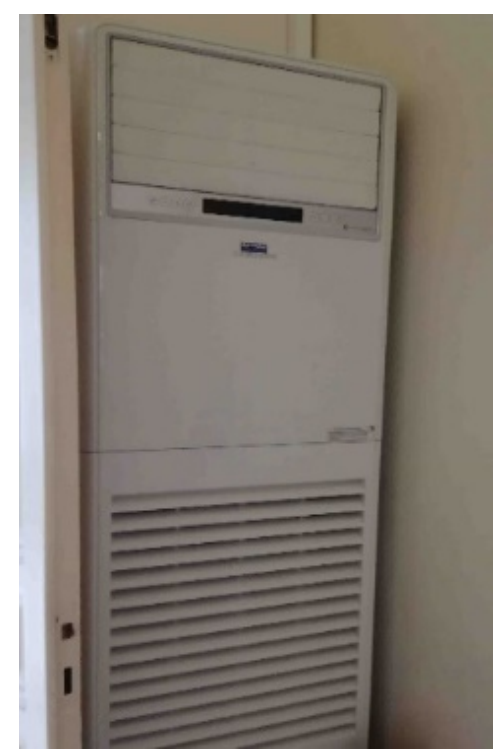

Şekil 13. Denizli Atatürk ve Etnografya Müzesi’nde Bulunan İklimlendirme Cihazı

Tablo 2 .

Nemli Ortamlarda Organik ve İnorganik Malzeme Bozulmaları (Kuzucuoğlu, 2010, s. 18).

\begin{tabular}{|c|l|}
\hline & \multicolumn{1}{|c|}{ Nemli Ortamda } \\
\hline Organik Malzemeler & $\begin{array}{l}\text { Sertleşme, çürüme, kırılganlaşma, boyutlarda değişim, } \\
\text { renk değişimi, yumuşama, bakteri oluşumu. }\end{array}$ \\
\hline İnorganik Malzemeler & Çatlak oluşumu, kopma, ayrışma, çiçeklenme, korozyon. \\
\hline
\end{tabular}

Kapalı ortamlarda havanın sıcaklığını, nemini ve kalitesini ayarlayan iklimlendirme cihazlarının bulunması ve sürekli çalıştırılması gerekmektedir. (Bkz. Fotoğraf. 13). Nem ve nem hareketindeki değişiklikleri izlemek için cihazların kullanılması ve risk faktörlerinin izlenmesi gerekmektedir (Finke, 2008, s. 8). Bağıl nem değerlerinin kontrolü için ise nem ayarlayıcılar ya da silika-jel kullanılabilir (Baydar, 2001, s. 107). Isı ve nem farkları arttıkça müzede bulunan kültür varlıkları bozulmaya başlayabilir bununla birlikte önlem alınmadığı takdirde tüm eserler zarar görebilir. Örneğin kontrolsüz nem ortamında yer alan mikroorganizmalar, organik eserlerin yapılarını ayrıştırarak yok olmalarına neden olurlar (Alpaslan Arça, 2009, s. 121). Özellikle müzeye dönüştürülen tarihi yapıların iyi bir yalıtımı olmadığı durumlarda nem oranı kontrol edilemez bir hal alacak ve eserler zarar görecektir. Malzemeler aynı koşullarda, aynı iklimde aynı özellikleri göstermezler. Her malzeme farklı duyarlılıklara sahiptir. Neme karşı duyarlı olan malzemeler titizlik ile denetlenmelidir. Yüksek nem her daim bozulma sürecini arttırıcı özelliktedir. Beraberinde biyolojik oluşumlar ile kimyasal etkinliği getirerek malzemelerde tahribatın oluşmasında önemli rol oynarlar. Nemli, kapalı mekânların sürekli havalandırılmasında fayda vardır. Yapıda nem problemi var ise bunlar en çok dış beden duvarları ile zeminde kendini belli etmektedir (Bkz. Şekil. 14). Bu alanlarda eserler sergileniyor ise nemin etkisinin azaltılması için dış duvarlar ve zemine oturan döşemeler ile üzerindeki eserin bulunduğu bölüme nem etkisini azaltan bir 
yalıtım, tabaka koyulması faydalı olacaktır. Örneğin kurşun levha koyulabilir (ICCROM, 1987, s. 14). Nem oranı: metal eserler, taş eserler, seramikler için \% 0-\% 45, cam eserler için \% 42-\%45 arasında, organik eserlerde \%50-\%65 arasında korunmalıdır (Erdal, 1989, s. 323). Genel anlamda eserlerin bulunduğu müzelerde havadaki nem \%55 rölatif nem oranı sabitinde kalmalıdır (Koyuncu Okca, 2014, s. 93).

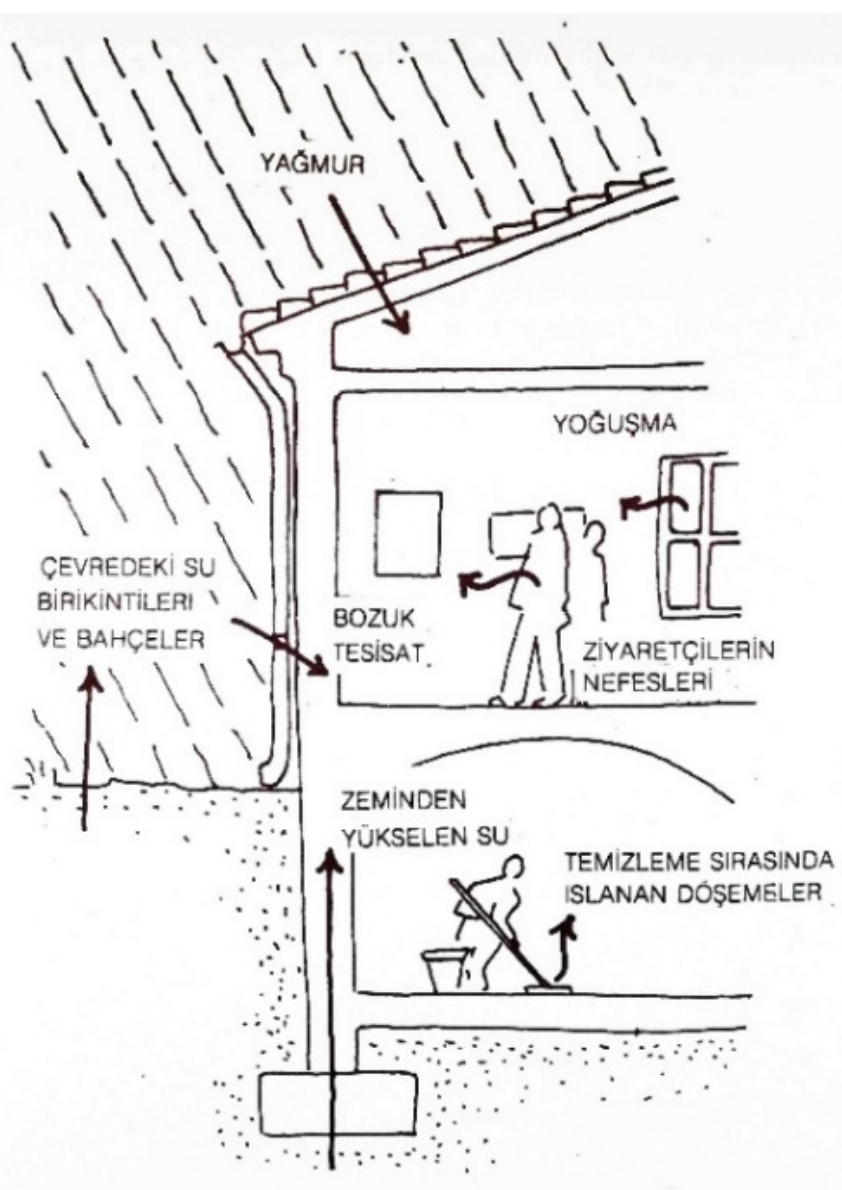

Şekil 14. Müzelerin Zemin, Çatı, Dış Duvar, Su Tesisatı ve Ziyaretçilerin Neden Olduğu Nem Sorunu (ICCROM, 1987, s. 8)

Higroskopik (nem çekici) özellikteki ahşap vitrin, bu vitrini kaplayan kumaş ya da görülmeyecek noktalara yerleștirilen pamuklar gibi organik malzemeler bağıl nemi dengelemede ve etkisini azaltmada kullanılabilirler. Nem dengeleyici özelliğinin yanında fazla nemin metal gibi soğuk yüzeylerin üzerinde yoğuşmasını da önler. 
Tablo 3.

Malzeme Üzerindeki Etkiler ve Kabul Edilebilirlik Seviyeleri (Cavallini vd., 1991, s. 627)

\begin{tabular}{|c|c|c|c|c|c|}
\hline MALZEME & BOZULMA & $\begin{array}{l}\text { ÇEVRESEL } \\
\text { FAKTÖRLER }\end{array}$ & $\begin{array}{c}\text { MİKROBİYOLOJİK } \\
\text { FAKTÖRLER }\end{array}$ & $\begin{array}{l}\text { BAĞIL } \\
\text { NEM (\%) } \\
\text { Max. - Min. }\end{array}$ & $\begin{array}{l}\text { SICAKLIK } \\
\quad\left({ }^{\circ} \mathrm{C}\right) \\
\text { Max. - Min }\end{array}$ \\
\hline Tekstil & $\begin{array}{l}\text { Ağsı dokuma malzeme } \\
\text { gerilir ve küçülür. Pamuk } \\
\text { ve keten gibi ipek ve yün } \\
\text { de nemin zararlı } \\
\text { etkilerine karşı hassastır. } \\
\text { Boyalı malzemeler nem } \\
\text { değişimlerine karşı daha } \\
\text { da hassastır. }\end{array}$ & $\begin{array}{l}\text { Kirlilik, toz ve } \\
\text { 1şık. }\end{array}$ & $\begin{array}{l}\text { Genel olarak küf } \\
\text { gelişimi ve } \\
\text { mikroorganizmalar. }\end{array}$ & $60-50$ & $30-15$ \\
\hline Kağıt & $\begin{array}{l}\text { Koşulların aşırı derecede } \\
\text { değişmesi ile birlikte } \\
\text { esneklik kaybı. }\end{array}$ & Kirlilik ve 1şık. & $\begin{array}{l}\text { Küflenmeye aşırı } \\
\text { duyarlılık. }\end{array}$ & $60-50$ & $30-15$ \\
\hline $\begin{array}{l}\text { Kemik ve } \\
\text { Fildişi }\end{array}$ & $\begin{array}{l}\text { Bozulma süreci yavaştır; } \\
\text { ince ve yüzeysel } \\
\text { tabakalarda biraz daha } \\
\text { hızlıdır. }\end{array}$ & $\begin{array}{l}\text { Fosforesan } \\
\text { aydinlatma } \\
\text { tavsiye edilir. }\end{array}$ & & $60-50$ & $30-15$ \\
\hline Ahşap & $\begin{array}{l}\text { Katmanlarla ilgili } \\
\text { değişken ve yavaş süreç. } \\
\text { Mevsimsel döngülere } \\
\text { duyarl. }\end{array}$ & Kirlilik. & $\begin{array}{l}\text { Nen oranı yüksek } \\
\text { olduğunda } \\
\text { mikroorganizmalar } \\
\text { ahşabı istila eder. }\end{array}$ & $60-50$ & $22-15$ \\
\hline Metal & $\begin{array}{l}\text { Korozyon: \% } 30 \text { bağıl } \\
\text { nemde dokuz aylık bir } \\
\text { süreçte } \\
\text { gelebilir. Pirinç ve bronz } \\
\text { \%15 ya da daha düşük } \\
\text { seviyelerde oksitlenmez. }\end{array}$ & $\begin{array}{l}\text { Sicaklık } \\
\text { değişimi ve } \\
\text { kirleticiler } \\
\text { metallerin } \\
\text { bozulmasında } \\
\text { etkin rol } \\
\text { oynar. }\end{array}$ & & $45-40$ & $35-5$ \\
\hline
\end{tabular}

\section{Aydınlatma ve Işık}

Müzede sergilenen kültür varlıkları çeşitlerine göre farklı kimyasal özellikler barındırırlar. Bu neden ile aynı ışığın etkisinde bulunsalar dahi farklı duyarlılık sergilerler. Eserlerin malzemesine göre farklı aydınlık değerleri söz konusudur. Taş, seramik, metal gibi inorganik eserler ışı̆̆a karşı duyarsız nesnelerdir bu nedenden dolayı 300 lüks 1şık seviyesine kadar sergilenebilmektedir (Bonvicini, 2010, s. 25). Lüks: Aydınlatma yoğunluğu ölçü birimidir (Adcock, 1998, s. 5). Yağlı boya, kemik, fildişi gibi düşük duyarlılığa sahip nesneler 150 lüks (Michalski, 2004, s. 78), dokuma eserler, pullar, minyatürler gibi eserler 50 lüks, ipek, eski gazete kâğıdı, eski kitap, eski yazma eserler ise yüksek duyarlılığa sahip oldukları için 30 lüks ışık seviyesine kadar sergilenebilmektedir (ICCROM, 1987, s. 20).

Hem güneş 1şığının hem de yapay ışı̆̆ın etkisi organik ve inorganik eserlerde bozulmaya neden olurlar. Özellikle güneş ışığını doğrudan gören kumaşlarda, renklerde solma ve deformasyon görülmektedir (Alpaslan Arça, 2009, s. 121; ICCROM, 2016, s. 40). Bu sebep ile müzelerde bulunan kültür varlıklarının mümkün olduğu 
kadar zararlı ışıklardan uzak tutulmalıdır. Eserlere doğrudan ışık verilmesi bozulma sürecini hızlandırır UV gibi zararlı ışınları engelleyen ve etkisini azaltan filtreler kullanmakta fayda vardır. Işı̆ğa karşı aşırı derecede duyarlı malzemeler için 50 lüks aydınlık değeri standart olarak kabul edilir ve bu değerin üstüne çıkılmamalıdır. 50 lüks ışık değerindeki aydınlatma görme için yeterli bir aydınlık seviyesidir, renk ayrımı için 10-30 lüks ışık değeri alt değer olarak kabul edilir (Macleod, 1978, s. 10). Ayrıca eserlerin uzun süreli ışık altında kalması, koruma anlamında istenilmeyen bir durumdur bu yüzden ziyaretçilerin olmadığı zamanlarda aydınlatma sisteminin otomatik kapatılması ile uzun süreli gösterimlerin kesilmesi koleksiyonların korunmasinda etkin bir rol oynar (Dorge and Jones, 1999, s. 153).

\section{Denizli Atatürk ve Etnografya Müzesi'nde Çevresel Koşulların Denetimi}

Denizli Atatürk ve Etnografya Müzesi'nin bulunduğu konumda gece ile gündüz arası sıcaklık farklılıkları bulunmaktadır. Makro klima olarak bu eserler için sorun teşkil etse de mikro klima olarak müze içerisinde bulunan iklimlendirme cihazları sayesinde bu sıcaklık değerleri sabit kalabilmektedir. Müzede girişin sol tarafında bir adet, ikinci kat koridorunun sonunda bir adet olmak üzere toplam iki adet iklimlendirme cihazı mevcuttur. Bu cihazın sürekli çalışması büyük nem dalgalanmalarına ve artan iç mekan nem seviyelerine neden olduğu için otomatik fan modu ayarlanarak ihtiyaç halinde çalışması sağlanmaktadır. Bu sayede hem fazla enerji tüketimi engellenmiş hem de fan 1sısı dengelenmiştir. Söz konusu cihaz çalıştı̆̆ında rahat sağlıklı bir iç ortam sağlar. Cihazın ısıtma sistemi devreye girdiği zaman kısmi yükte alan sıcaklığını ve bağıl nemin kontrolünü sağlar (Wang, 2000, s. 2).

Müzede kaloriferli ısıtma sistemi olmasına karşın ısıtma işlemleri bu iklimlendirme cihazları ile yapılmaktadır. Kaloriferli ssıtma sistemi tamamen iptal edilip eserler ve müze için uygun olan bu iklimlendirme cihazları kullanılmaktadır. İklimlendirme cihazları ile sıcaklığın sürekli kontrol altında tutulması $\left(18-21^{\circ} \mathrm{C}\right)$ eserlerin stabil bir ortamda sergilenmesi ve depolanması nem düzeyinin de dengede tutulması demektir. Sicaklık eserlerin bozulma durumlarına dolaylı olarak etki eder ama sabit tutulduklarında nemin de kontrolü ile eserler tam istenilen bir koruma ortamında bulunurlar. Bu yüzden sıcaklığın sabit tutulması önem teşkil etmektedir. Müzede genel olarak ölçülen bağıl nem \%50'dir ve +5 ile -5 değerleri arasında değişmektedir. Bu durum hem organik hem de inorganik eserler için normal bir değerdir. Fakat vitrin içerisine nem düzenleyiciler bulunmamaktadır. Her malzeme farklı duyarlılıklara sahip olduğu için farklı özellikler gösterirler. Bu yüzden her seksiyonun ayrıca bir nem düzenleyicisinin bulunması gerekmektedir.

Sergileme ve depolama alanları arasında aşırı ısı ve nem farkı yoktur. Bunun nedeni ise depolama alanının üst katta yer alması ve aynı katta eserlerin sergilenmesidir. Bu katta bir adet iklimlendirme cihazı ile sıcaklık sabit tutulmuş ve nem dengesi kontrol edilmeye çalışılmıştır. Denizli Atatürk ve Etnografya Müzesinin tarihi bir yapıdan müzeye dönüştürüldüğünü göz önünde bulundurulduğunda nem değerlerinin kontrol altında tutulduğunu söylenebilir. Bu durum yağmurlu havalar ile ziyaretçilerin yoğun olduğu zamanlarda değişiklik gösterebilmektedir. Müzenin çatısında herhangi bir problem olmadığ gözlemlenmiştir. Restorasyonu 2006 yılında tamamlanan müzenin bu konu ile ilgili gerekli bakımları yapılmıştır. Zemin ile ilgili olarak müze uzmanları daha önce zeminde su çıktığını ve drenaj problemi olduğunu fakat bu problemin mühendisler tarafından gerekli önlemler alınarak bertaraf edildiğini ve çözüme kavuştuğunu belirtmiştir. Eğer müzede nem problemi bulunsaydı bunlar en çok zemin ve duvarlarda görülürdü. Müzede gözlemlenen herhangi bir nem problemine rastlanmamıştır. Rutin bina bakımı, önleyici koruma çalışmalarına hizmet edebilir. Pencerelerin ve çatının iyi durumda olduğundan emin olmak, nem hasarını önleyebilir ve objeler üzerinde baskı oluşturan orta dereceli sıcaklık dalgalanmalarına yardımcı olabilir (Getty Conservation Institute, 1994, s. 95).

Müzede nem değerini ölçmek için giriş katındaki koridorda bir adet, ikinci kattaki koridorda iki adet, depoda bir adet, olmak üzere toplam dört adet DS-100 marka nemölçer bulunmaktadır. Bu alet hem 1sı değerlerini hem de nem değerlerinin sayısal olarak vermekte olup 24 saatte 24 kayıt yapmaktadır. Nemölçerlerin ayarları 
uzman restoratörler tarafından 3 ayda bir yapılmakta olup, aylık kayıt altına alınmaktadır. Sergileme alanlarının vitrin ve raf malzemesi ahşaptır. Bu ahşap malzeme ise kumaş ile kaplanmıştır (Bkz. Şekil. 15).

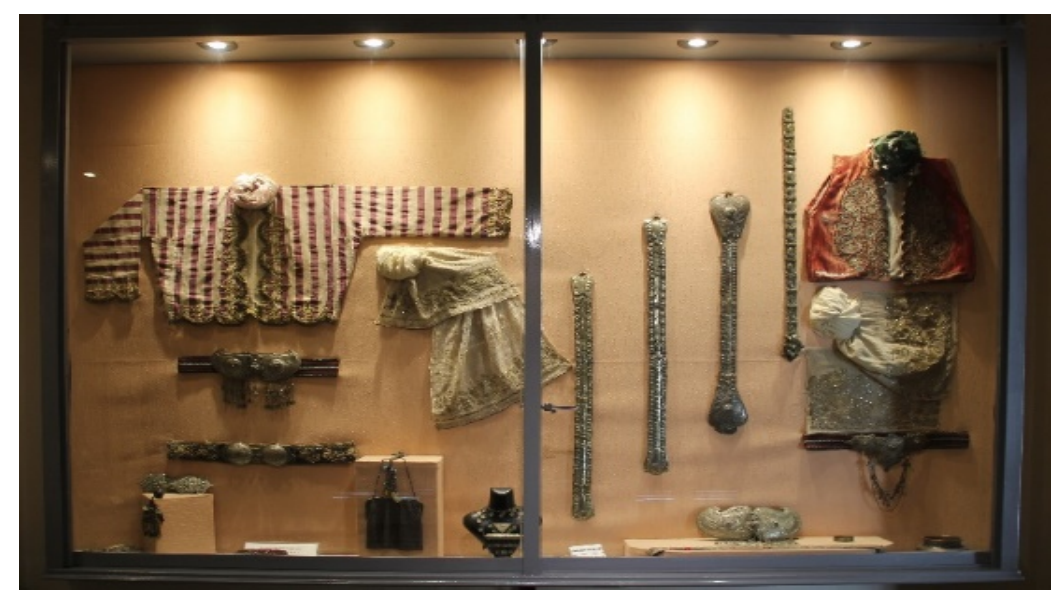

Şekil 15. Gümüş Takılar Odasından Bir Ahşap Vitrin Örneği

Ahşap vitrinler darbeye ve sarsıntıya karşı alttan güçlendirme yapılarak sağlamlaştırılmıştır. Fakat ne kadar sağlamlaştırma yapılsa da eski oldukları için değiştirilmesi eserler adına yaralı olacaktır (Bkz. Şekil. 16).

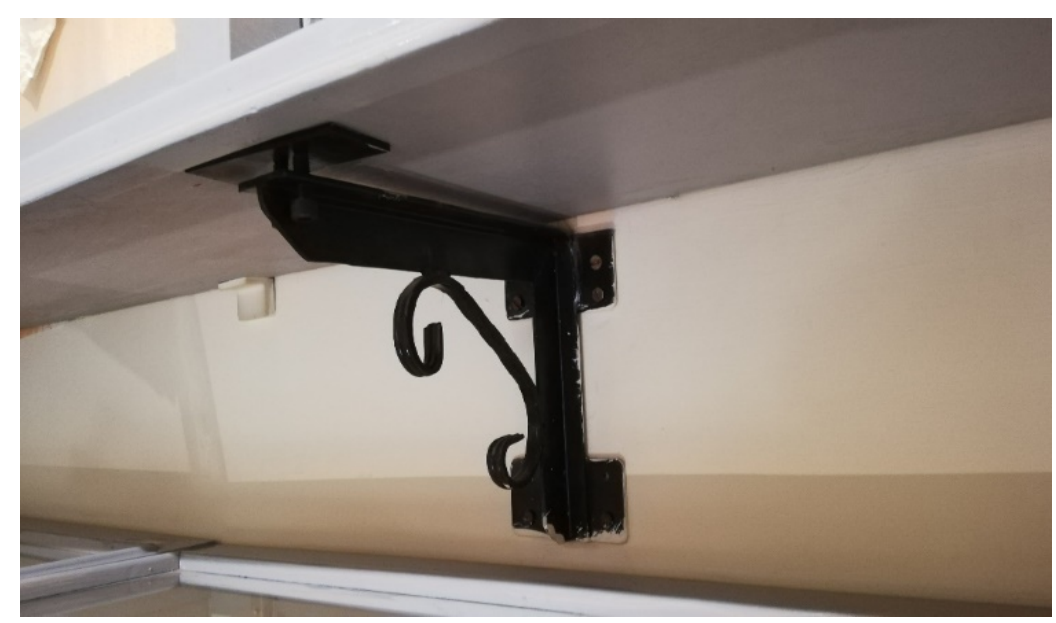

Şekil 16. Alttan Destek Yapılarak Sağlamlaştırılan Ahşap Vitrinler

Vitrinler savunmasız olan eserleri toz birikiminden korur (Camuffo, 2014, s. 27). Müzenin konumu, Denizli'de en yoğun insan ve araç trafiğinin yaşandığı yer olması nedeni ile vitrinler eserleri toza karşı kısmen koruyabilmektedir. Her ne kadar pencerelerde cam aralığı olmamasına dikkat edilse de toza karşı vitrinlerin yetersiz olduğu gözlemlenmiştir. Sergileme alanlarında ortam aydınlatması için Tij (metal askı teli) sistemi kullanılmış ve spot lambalar ile yapay ışıklandırma sağlanmıştır (Bkz. Şekil. 17-19). Sergileme alanlarında aydınlatma seviyesinin sabit olması, kısmen sıcaklığı etkilemesi açısından olumsuz bir durumdur. Aynı durum vitrin içi aydınlatmalarda da geçerlidir. 


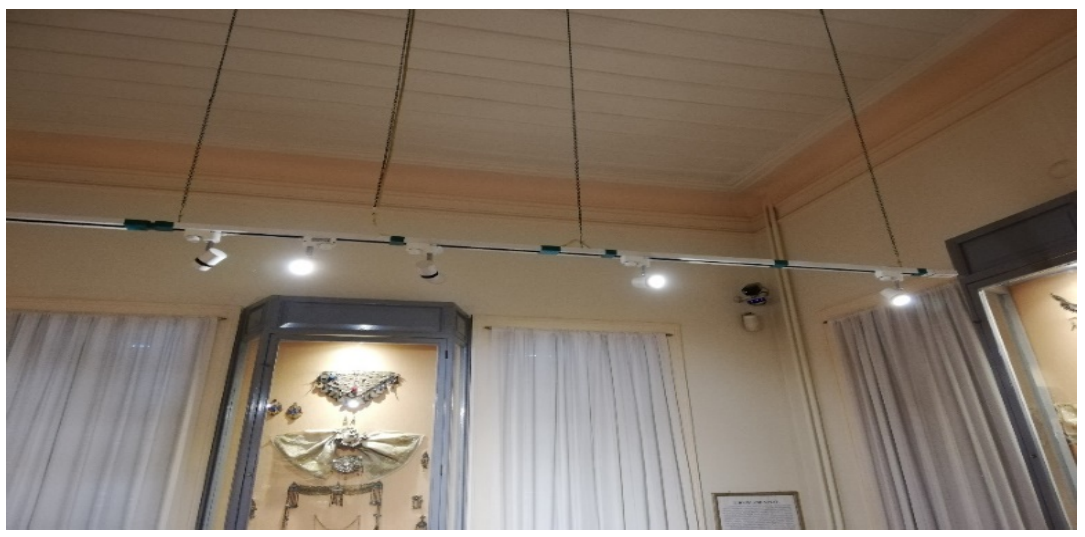

Şekil 17. Müzede Tij (Metal Askı Teli) ve Spot Lambalar ile Sağlanan Yapay Işıklandırma

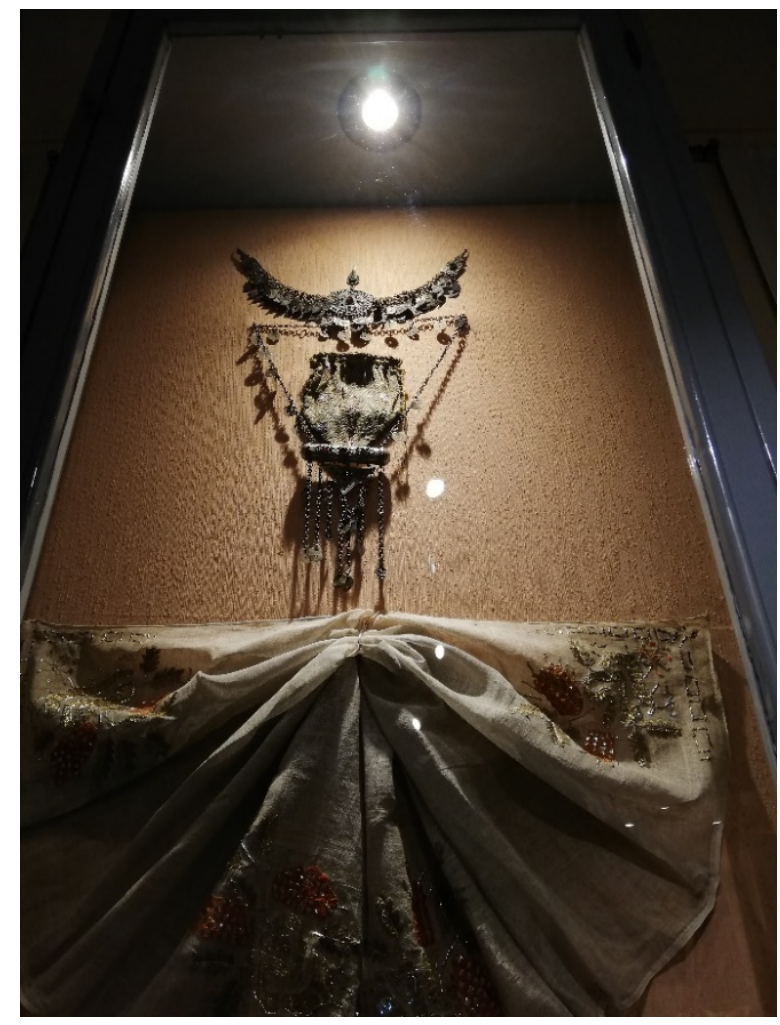

Şekil 18. Vitrin İçinde Spot Lambalar ile Sağlanan Yapay Işıklandırma 


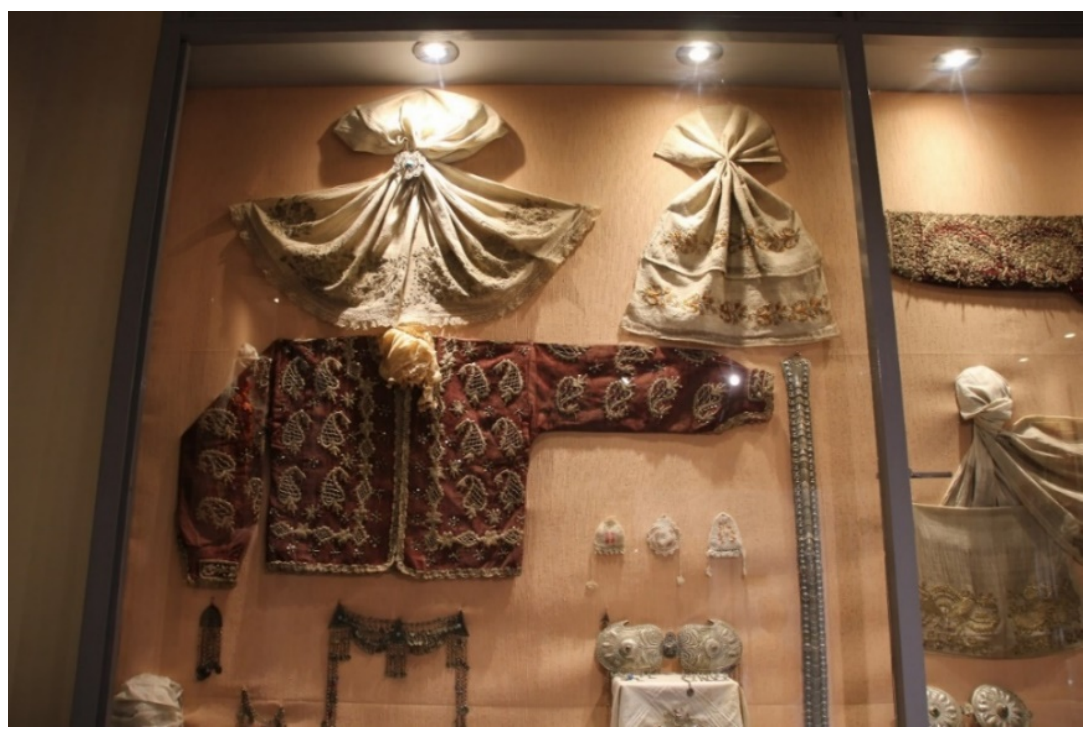

Şekil 19. Vitrin İçinde Spot Lambalar ile Sağlanan Yapay Işıklandırma

\section{Değerlendirme ve Sonuç}

Farklı disiplinlerin bir arada detaylı bir çalışma sonucu oluşturdukları müzeler ile yeni işlevler getirerek eski yapıların restorasyon ve konservasyon çalışmaları sonucu oluşturdukları müzeler arasında farklılıklar vardır. Yeni tasarlanan, planlanan yani baştan yaratılan müzelerde iyi imkânlar ile kültür varlıklarının sergileme ve depolama çalışmaları uzmanlar tarafından rahat bir şekilde yapılırken, eski yapılarda çok fazla ek ve değişiklikler yapılamadığından dolayı sergileme ve depo alanlarında birtakım sorunlar ile karşılaşılmaktadır. Bu durum müzedeki eser kontenjanına sınır getirmek ile beraber çevresel denetim koşullarına da olumsuz etki edebilmektedir. Bu tip müzelerde çalışan uzmanlar, sorunlar karşısında çözüm üreterek eserleri en uygun koşullar altında sergilemeye ve depolamaya çalışmaktadır.

Denizli Atatürk ve Etnografya Müzesi de restore edilerek müzeye dönüştürülmüş bir binada hizmet vermektedir. $\mathrm{Bu}$ yüzden bu binanın müze olarak hizmet verebilmesi için gerekli bakımlar ve onarımlar yapılmış, ortam eserler için en uygun hale getirilmiştir. Yapının planı müze için yeterli büyüklükte olmasa da pek çok eser sergilenerek ziyaretçilerin beğenisine sunulmuştur. Müzelerin en temel sorunları arasında yer alan nem problemi yapısal anlamda drenaj sistemi ile çözülmüş, iç mekanlarda ise nem düzenleyiciler ile stabil durama getirilmiştir.

Müze uzmanları ile yapılan görüşmeler ve gözlemler neticesinde, tarihi bir yapıdan müzeye dönüştürülen bu binada çevresel denetim koşullarına dikkat edildiği belirlenmiştir. Müze bulunduğu konum itibari ile araç trafiği ve insan kalabalığına maruz kalarak beraberinde hava kirliliğini de getirmektedir. Eserler için olumsuz bir durum olan hava kirliliğini kontrol altında tutmak elbette güçtür, fakat müze içinde bulunan iklimlendirme cihazları sayesinde hem nem dengesi hem $1 s$ hem de müze içindeki havanın kontrolü sağlanmıştır. Müzede kaloriferli ısıtma sisteminin tamamen iptal edilmesi ve yerine iklimlendirme cihazlarının kullanılması, eserler adına kontrollü ve dengeli bir ısı ortamının oluşmasını sağlamış ve nem dengesini stabil hale getirmiştir. Fakat her eserin aynı nem dengesinde tutulması olumsuz bir durumdur. Bunun için vitrin ve depo bölümlerine farklı nem düzenleyiciler gerekmektedir. Nemin kontrol edilmediği durumlarda nem değerinin yükselmesi veya düşmesi eserlerde hızlı bozulmalara neden olacaktır. $\mathrm{Bu}$ yüzden vitrin içinde nem düzenleyicilerin bulunmasinda fayda vardır. 
Sergileme alanlarının ahşaptan olan vitrinleri eski olduğu için değiştirilmesi önerilmektedir. Vitrinlerin ve sergileme alanlarının aydınlatma seviyeleri sabit ışık altında olduğu için eserlere uygun değildir. Sergilenen eserler aynı ışık etkisinde farklı duyarlılıklar gösterdikleri için malzeme çeşitliliğine göre farklı aydınlık değerleri kullanmakta yarar vardır. Morötesi ışınım ile görünür ışık ve aydınlık seviyesi ölçülmeli ardından kontrol altına alınmalıdır. Müzede sadece yapay ışık ile aydınlatma durumu söz konusudur. Güneş ışığının hem perde hem de panjur ile kırılması organik ve inorganik eserlerin bozulmasını engellemektedir.

Müzede bulunan kültür varlıklarının koruma ve onarım çalışmaları Denizli Müze Müdürlüğü tarafından görevlendirilen uzman restoratör ve konservatörler ile gerçekleştirilmektedir. Müdahale edilmesi zorunlu hale gelen eserler uzmanlar tarafından titizlik ile incelenerek gerekli koruma sağlanmaktadır. Çevresel koşulların denetimi ile de ilgilenen uzmanlar gerekli yerlerde fikirlerini beyan edip eserlerin korunması, bozulmaya neden olan unsurların en aza indirilmesi ve doğru koşulların sağlanması için çözümler üretmişlerdir.

Eserleri korumak, onları uygun ortam koşullarında muhafaza etmek ve kültür varlıklarını gelecek nesillere aktarmak müzelerin en temel görevidir. Bu sayede kültürel miras bilincine sahip insan sayısı giderek artacak, müzelerin sürdürülebilirliği sağlanarak gelecek nesiller ecdatlarının bıraktığı bu mirasa bilinçli ve kararlı bir şekilde sahip çıkacak, onları anlayacak ve anlatacaktır.

\section{Kaynakça}

Adcock, E. P. (1998). IFLA Principles for the care and handling of library material. Paris: IFLA PAC. Erişim adresi: https://www.ifla.org/files/assets/pac/ipi/ipi1-en.pdf

Alpaslan, A. S. (2009). Topkapı Sarayı Müzesi kumaş deposundaki tekstilin korunmasına yönelik yapılan çalışmalar. F. Bayram ve A. Özme (Yay. haz.). 17. Müze Çalışmaları ve Kurtarma Kazıları Sempozyumu, 28 Nisan - 1 Mayıs 2008, Side, Türkiye, bildiriler içinde (s. 119-130). Ankara: T.C. Kültür ve Turizm Bakanlığı. Erişim adresi: http://www.kulturvarliklari.gov.tr/sempozyum_pdf/muze_kurtarma/17_muze_kurtarma.pdf

Al-Saad, Z. (2013). Course outline: Preventive Conservation. Paris: UNESCO World Heritage. Erişim adresi: https://whc.unesco.org/document/6819+\&cd=2\&hl=tr\&ct=clnk\&gl=tr

Altınoluk, Ü. (1988). Eski yapılar yeni fonksiyonlar. İstanbul: Türkiye Turing ve Otomobil Kurumu.

Altınsapan, E. ve Küçükhasköylü, N. (2013). Müzecilik ve sergileme. Eskişehir: Anadolu Üniversitesi Yayınları.

Atasoy, S. (1994). Çağdaş müzecilik anlayışı ve Türk müzeciliği. Anons Plastik Sanatlar Dergisi, 41(42), 38-39.

Ayaokur, A. (2014). Müzelerde bilgi yönetimi: Sadberk Hanım Müzesi örneği (Yayımlanmamış yüksek lisans tezi). Hacettepe Üniversitesi, Ankara.

Baydar, N. (2001). Müzelerdeki organik eserler hangi koşullarda depolanmalı ve eserlere nasıl muamele edilmelidir?. 5. Müzecilik Semineri Bildiriler, 107-111.

Baysal, H. H. ve Kayhan, R. (2016). Denizli kültür envanteri. Denizli: T.C. Denizli Valiliği İl Kültür ve Turizm Müdürlüğü.

Boersma, F. (2016). Preventive conservation - 'more than dusting objects'? An overview of the development of the preventive conservation profession. Journal of the Institute of Conservation, 39(1), 3-17. doi:10.1080/19455224.2015.1136463 
Bonvicini, C. (2010). Conservazione preventiva e controllo microclimatico nel contesto degli standard museali. Siena: Santa Maria della Scala, Erişim adresi: https://www.regione.toscana.it/documents/10180/70936/Conservazione\%20preventiva\%20e\%20cont rollo\%20microclimatico\%20nel\%20contesto\%20degli\%20standard\%20museali/a7e39bf9-ec68-4c1387a9-a14902c75eec

Bülbül, H. (2016). Yozgat Etnografya Müzesi örneği ile yaşayan kültürün aktarımı. K. Özköse (Ed.). I. Uluslararası Bozok Sempozyumu Bildiri Kitabı, 3, 05 - 07 Mayıs 2016, Yozgat, Türkiye, bildiriler içinde (s. 216-228). Yozgat: Bozok Üniversitesi. Erişim adresi: https://silo.tips/download/yozgat-etnografyamzes-rne-le-yaayan-kltrn-aktarimi

Camuffo, D. (2014). Microclimate for cultural heritage. Amsterdam: Elsevier. doi:10.1016/C2013-0-00676-7

Caneva, G., Nugari, M. P. ve Salvadori, O. (1991). Biology in the conservation of work of art. Rome: ICCROM. Erişim tarihi: https://www.iccrom.org/sites/default/files/201802/1991_caneva_biology_51352_light.pdf

Caneva, G., Mandrioli, P. ve Sabbioni, C. (2003). Cultural heritage and aerobiology. Bologna: SEPS. doi:10.1007/978-94-017-0185-3

Cavallini, T., Massa, S. ve Russo, A. (1991). Optimal environmental conditions in museums. N. S. Baer, C. Sabbioni ve A. I. Sors (Yay. haz.), Science, Technology and European Cultural Heritage içinde, (s. 626631). Oxford: Butterworth-Heinemann. doi:10.1016/B978-0-7506-0237-2.50104-0

Çıkış, Ş. (2009). Modern konut olarak XIX. yüzyıl İzmir konutu: biçimsel ve kavramsal ortaklıklar. METU JFA, 2(26), 211-233. Erişim adresi: http://jfa.arch.metu.edu.tr/archive/0258-5316/2009/cilt26/sayi_2/211233.pdf

De Nuntiis, P., Franco, P. ve Fabio, P. (2012). Preventive conservation. B. Fabbri (Ed.), Science and Conservation for Museum Collection içinde, (s. 14-52). Firenze: Nardini Editore.

Doğruer, F. S. (2019). Müzelerde önleyici koruma: Temel yaklaşımlar ve gelişimi. Akademik Sanat Dergisi, 7(4), 121-134. Erişim adresi: https://dergipark.org.tr/tr/download/article-file/776399

Dolar, A. ve Yılmaz, E. Ş. (2014). Kültürel yapılarda biyolojik bozulma mekanizmaları. Elektronik Mikrobiyoloji Dergisi, 12(1), 1-19. Erişim adresi: www.mikrobiyoloji.org/pdf/702140101.pdf

Dominique, P. (2003). Another history of museums: From the discourse to the museum-piece. Anais do Museu Paulista, 21(1), 27-47. doi:10.1590/S0101-47142013000100004

Dorge, V. ve Jones, L. S. (1999). Building an emergency plan a guide for museums and other cultural institutions. Los Angeles: The Getty Conservation Institute. Erişim adresi: https://www.getty.edu/conservation/publications_resources/pdf_publications/pdf/emergency_plan.p df

Erdal, B. (1989). Müzelerimizde sergilenen taşınır arkeolojik ve etnoğrafik kültür varlıklarımızın bozulma sebepleri ve koruma (konservasyon) metotları. Türk Arkeoloji Dergisi, 28, 323-332.

Fangqing, L. (2017). Museum architecture as spatial storytelling of historical time: Manifesting a primary example of jewish space in Yad Vashem Holocaust History Museum. Frontiers of Architectural Research, 6(4), 442-455. doi:10.1016/j.foar.2017.08.002

Finke, A. L. (2008). Implementing preventive architectural conservation: Do historic property stewards in the United States possess the tools to meet the challenge?. (Yüksek lisans tezi, Pennsylvania Üniversitesi, Philadelphia). Erişim adresi: https://core.ac.uk/download/pdf/76361378.pdf 
Fromm, A. B. (2016). Ethnographic museums and intangible cultural heritage return to out roots. Journal of Marine and Island Cultures, 5(2), 89-94. doi:10.1016/j.imic.2016.10.001

ICCROM. (1987). Müzelerde koruma: Çevresel koşulların denetimi. İstanbul: T.C. Kültür ve Turizm Bakanlığı, Eski Eserler ve Müzeler Genel Müdürlüğü.

ICCROM. (2016). A guide to risk management of cultural heritage. Ottawa: Canadian Conservation Institute. Erişim adresi: https://www.iccrom.org/wp-content/uploads/Guide-to-Risk-Managment_English.pdf

ICOM. (2017). Statutes, as amended and adopted by the extraordinary general assembly. ICOM: Paris. Erişim adresi: https://icom.museum/wp content/uploads/2018/07/2017_ICOM_Statutes_EN.pdf

ICOMOS. (1964). International charter for the conservation and restoration of monuments and sites. Venice: The Venice Charter. Erişim adresi: https://www.icomos.org/charters/venice_e.pdf

James, S. (2000). Museums in the German art world from the end of the old regime to the rise of modernism. Oxford: Oxford University Press.

Karabay, N. (2007). Atatürk ve etnografya müzesi. Geçmişten Günümüze Denizli, 15(1), 2-7. Erişim adresi: http://dergi.csavakfi.org.tr/sayilar/sayi15/files/assets/basic-html/page-1.html\#

Knell, S. (1994). Care of collections. London: Routledge.

Kocaeli, F. ve Eskici, B. (2017). İç Anadolu Bölgesi müzelerinde önleyici koruma sorunları üzerine bir değerlendirme. Restorasyon-Konservasyon Çalışmaları Dergisi, 20, 53-64. Erişim adresi: https://dergipark.org.tr/tr/download/article-file/624653

Koçak, E. ve Eskici, B. (2019). Müzelerde korumaya etkiyen faktörler. Sanat ve Tasarım Dergisi, 24(1), 235258. Erişim adresi: https://dergipark.org.tr/tr/download/article-file/903037\#

Koyuncu Okca, A. (2014). Geleneksel dokumalarda koruma ve onarım prensipleri (Yayımlanmamış yüksek lisans tezi). Pamukkale Üniversitesi, Denizli.

Koyuncu Okca, A. ve Özar, H. (2015). Denizli Atatürk ve etnografya müzesi. Akademik Sosyal Araştırmalar Dergisi, 14, 194-206. doi:10.16992/ASOS.723

Kökten, H. (2007). Müzede koruma. Ankara: Ankara Üniversitesi Uzaktan Eğitim Yayınları (ANKUZEM).

Kuzucuoğlu, A. H. (2010). Müzelerde iklim ölçümleri ve pasif konservasyon. Restorasyon-Konservasyon Çalışmaları Dergisi, $\quad 6, \quad 17-22 . \quad$ Erişim adresi: https://dergipark.org.tr/tr/pub/restorasyon/issue/48684/619372

Kuzucuoğlu, A. H. (2011). İstanbul Beylerbeyi Sarayında risk analizleri ve koruyucu tedbir önerileri (Yayımlanmamış doktora tezi). İstanbul Üniversitesi, İstanbul.

Lewis, G. (2004). The role of museums and the professional code of ethics. J. Boylan (Ed.), Running a museum: A pratical Handbook içinde, (s. 1-16). Paris: ICOM. Erişim adresi: https://unesdoc.unesco.org/ark:/48223/pf0000141067

Macleod, K. J. (1978). Museum lighting. Ottawa: National Museums of Canada.

Michalski, S. (2004). Care and preservation of collections. J. Boylan (Ed.), Running a museum: A pratical Handbook içinde, (s. 51-89). Paris: ICOM, Erişim adresi: https://unesdoc.unesco.org/ark:/48223/pf0000141067

National Park Service. (2016). The museum handbook part I: Museum collections environment. Washington DC: National Park Service Museum Management. Erişim adresi: https://www.nps.gov/museum/publications/mhi/mhi.pdf 
Oran, H. (1974). Atatürk Denizli'de. Denizli: Cumhuriyetin 50. Yılı İl Kutlama Kurulu Yayınları.

Ötgün, Ö. (2007). Atatürk evleri. Ankara: Kültür ve Turizm Bakanlığı Dösim Basımevi.

Öztürk, İ. (2003). Geleneksel Türk el sanatlarına giriş. İzmir: Dokuz Eylül Yayınları.

Plenderleith, H. J. (1957). The conservation of antiquities and works of art. London: Oxford University Press

Putt, N. ve Slade, S. (2004). Teamwork for preventive Conservation. Rome: ICCROM. Erişim adresi:https://www.iccrom.org/sites/default/files/publications/202104/iccrom_01_teamwork_en.pdf

Robert, L. (1988). The museum time machine: putting cultures on display. London: Routledge.

Rose, C. L., Catharine, A. H. ve Waller, R. (2019). A preventive conservation approach to the storage of collections. L. Elkin ve C. A. Norris (Ed.), Preventive conservation: collection storage, (s. 43-55) içinde. New York: Society for the Preservation of Natural History Collections. Erişim adresi: https://www.researchgate.net/publication/335682131_A_Preventive_Conservation_Approach_to_th e_Storage_of_Collections

Schultz, A. W. (1992). Caring for your collections. New York: Harry N. Abrams.

Serap, B. ve Levent, M. (2010). Görsel sanatlar eğitiminde müze eğitimi ve uygulamaları. Ankara: Öncü Basımevi.

Steen, A. (2004). Samdok: tools to make the world visible. S. J. Knell (Ed.), Museums and future of collecting, (s. 183-189) içinde. London: Routledge. doi: 10.4324/9781315248561

Stiff, M. (2007). Kültür mirasını koruma el kitabı 3 - Koleksiyonların belgelenmesi. İstanbul: UNESCO. Erişim adresi: https://kumid.net/storage/0h7hbpOxglSNq5IOMmNvpNaLlqxkTpY.pdf

Stulik, D. C., Druzik, J. R. ve Preusser, F. (1991). GCI - Environmental research program. N. S. Baer, C. Sabbioni ve A. I. Sors (Ed.), Science, technology and european cultural heritage, (s. 364-366) içinde. Oxford: Butterworth-Heinemann. doi:10.1016/C2013-0-04509-4

Uring, P., Chabas, A., Alfaro, S. ve Derbez, M. (2020). Assessment of indoor air quality for a better preventive conservation of some French museums and monuments. Environmental Science and Pollution Research, 27(34), 42850-42867. doi:10.1007/s11356-020-10257-6

Ünaldı, V. (2019). Kilim koruma ve onarım ilkeleri, meslek analizi ve uygulanabilirliği. (Yayımlanmamış sanatta yeterlik tezi), Gazi Üniversitesi, Ankara.

Wang, S. K. (2001). Handbook of air conditioning and refrigeration. New York: McGraw-Hill. Erişim adresi: https:/gmpua.com/CleanRoom/HVAC/Cooling/Handbook\%20of\%20Air\%20Conditioning\%20and \%20Refrigeration.pdf

Çalışmada kullanılan çizim ve fotoğraflar Berker Kalfa arşivinde yer almaktadır. 


\section{Extended Abstract}

\section{Purpose}

The concept of the museum has emerged as an institution that combines artifacts collecting, storing, archiving, documenting, researching, exhibiting and most important functions of preservation. Preserving the cultural heritage and keeping them under the best environmental conditions and transferring them to the future is the prior task of museums. It is crucial to intervene to minimize or decelerate the deterioration process, such as corruption, deterioration, degradation and, atmospheric conditions of cultural heritages to be transmitted to future generations and to take precautions to determine and implement protection methods. In this study, the evaluation of Denizli Atatürk and Ethnography Museum in terms of the control of the environmental conditions, whether the indoor environment quality, values, and balances of the temperature, light, humidity in the exhibition rooms and showcases are appropriate or not for the control conditions were investigated and various suggestions were aimed to come up with the best results.

\section{Design and Methodology}

This study aims to examine the exhibition and preservation conditions of the artifacts in the museum and to present suggestions for transferring the artifacts to the future in a more accurate, safe and contemporary way. In line with the stated purposes, international standards for heat, light and humidity values are specified in terms of the control of the environmental conditions in the museum. For this, the literature was searched and the necessary information on this subject was gathered. Denizli Atatürk and Ethnography Museum and exhibition rooms selected as a sample. In the museum, the hall on the ground floor, the sofa on the upper floor, the room for handicrafts, the room with silver jewelry, the gun section, the Denizli Sanjak and the room where the clothes of Hüseyin Efe from Selcen are exhibited, the study room and the bedroom of Atatürk, all the exhibition rooms, which are called the living room, day room, head room, and parent room were photographed, the areas and conditions in which they were exhibited, literature reviews consisting of studies on the control of the environmental conditions, individual determinations and interviews with museum officials were evaluated.

It has been examined that the air conditioning devices in the museum are not suitable for the works, and thanks to the humidity meter in the museum, temperature and humidity difference was observed between the exhibition and storage areas. It has been examined whether the lighting in the exhibition areas is suitable for the works. In addition, since the building is a historical mansion, information was obtained from the museum authorities about how the environmental conditions were provided in such a historical building and the necessary precautions were evaluated in this study.

As a result of the evaluations, suggestions were made for the ethnographic works, which have an important place for Denizli's urban memory and identity, to the future safely and with a modern understanding of museology. Necessary research permissions were obtained from Denizli Atatürk and Ethnography Museum and Denizli Provincial Directorate of Culture and Tourism for this study regarding the museum and all its exhibition rooms.

\section{Findings}

There are temperature differences between night and day at the location where Denizli Atatürk and Ethnography Museum is located. Although it poses a problem for these works as a macroclimate, these temperature values can remain constant thanks to the air-conditioning devices in the museum as a microclimate. There are two air conditioners in total, one on the left side of the entrance and one at the end of the second-floor corridor in the museum. Since the continuous operation of this device causes large humidity 
fluctuations and increased indoor humidity levels, automatic fan mode is set to ensure that it works when needed. In this way, both excessive energy consumption is prevented and the fan temperature is balanced. Although there is a central heating system in the museum, the heating processes are carried out with these air conditioning devices. The central heating system is completely canceled and these air-conditioning devices, which are suitable for artifacts and museums, are used. Keeping the temperature under constant control (18$21^{\circ} \mathrm{C}$ ) with air conditioning devices means exhibiting and storing the works in a stable environment and keeping the humidity level in balance. Temperature affects the deterioration of the artifacts indirectly, but when kept constant, the artifacts are in a completely desired preservation environment with the control of humidity. Therefore, it is important to keep the temperature constant. The relative humidity measured in the museum in general is $50 \%$ and varies between +5 and -5 values.

In the museum, there are a total of four DS-100 brand humidity meters, one in the corridor on the ground floor, two in the corridor on the second floor, and one in the depot. This instrument gives both temperature values and humidity values numerically and makes 24 records in 24 hours. The showcase and shelf materials of the exhibition areas are wood. This wooden material is covered with fabric.

Tij (metal suspension wire) system was used for ambient lighting in the exhibition areas and artificial lighting was provided with spot lamps. The fact that the lighting level is constant in the exhibition areas is a negative situation in terms of partially affecting the temperature.

\section{Research Limitations}

This article named "Denizli Atatürk and Ethnography Museum In Terms of the Control of the Museum and Environmental Conditions" deals with the indoor environmental quality in general, whether the temperature, light, humidity values and balances in the exhibition rooms and showcases are appropriate in terms of control conditions in terms of limits and scope.

\section{Implications}

As a result of the interviews and observations made with the museum experts, it was determined that the environmental control conditions were taken into consideration in this building, which was transformed from a historical building into a museum. Due to its location, the museum is exposed to vehicle traffic and crowds of people and brings air pollution with it. Of course, it is difficult to control air pollution, which is a negative situation for the artifacts, but thanks to the air-conditioning devices in the museum, both the humidity balance, the temperature and the air inside the museum are controlled. The complete cancellation of the central heating system in the museum and the use of air-conditioning devices instead, ensured the creation of a controlled and balanced heat environment for the artifacts and stabilized the humidity balance. However, keeping every piece of art in the same moisture balance is a negative situation. For this, different moisture regulators are required in the showcase and depot sections. In cases where the humidity is not controlled, the increase or decrease of the humidity value will cause rapid deterioration in the artifacts. Therefore, it is beneficial to have humidity regulators in the showcase.

It is recommended to replace the wooden showcases as they are old. Since the lighting levels of the showcases and exhibition areas are under constant light, they are not suitable for artifacts. Since the exhibited works show different sensitivities under the same light effect, it is useful to use different luminance values according to the material variety. Visible light and illuminance level should be measured with ultraviolet radiation and then controlled. There is only artificial lighting in the museum. The refraction of sunlight with both curtains and blinds prevents the degradation of organic and inorganic artifacts. 


\section{Originality}

Today, we still have museums under the threat of environmental conditions. This situation accelerates the deterioration process of our cultural assets and causes serious damage. It is important to take precautions to prevent all kinds of deterioration such as decay, wear and atmospheric conditions in the environments and museums where these cultural assets that need to be transmitted to the future under appropriate conditions, to determine and plan the protection methods, and to create the conditions that will provide ideal care. In this context, suggestions were made to examine the exhibition and preservation conditions of the artifacts in Denizli Atatürk and Ethnography Museum and to transfer the artifacts to the future in a more accurate, safe and contemporary way. Thus, the correct methods and techniques will be determined by preventing faulty practices in museums and will be a reference for future studies.

Araştırmacı Katkısı: Ayşegül KOYUNCU OKCA (\%50), Berker KALFA (\%50). 